\title{
On pigs and packers: Radically contextualizing a practice of science with Mexican immigrant students
}

\author{
Katherine Richardson Bruna · Roberta Vann
}

Received: 10 October 2006/ Accepted: 10 October 2006/Published online: 12 January 2007

(C) Springer Science+Business Media B.V. 2007

\begin{abstract}
This paper reports on instructional practices observed in a high school English Learner (EL) Science course serving newcomer Mexican immigrant youth. The school is located in a rural Midwestern meatpacking community in which labor at the hog plant is economically- and racially-segmented; it is the town's Mexican residents, many of them undocumented, who comprise most of the unskilled labor force. The general purpose of the paper is to document how the economic and racial context of this community influences science instruction in the EL Science course and to describe how this presents particular challenges in achieving equitable science instruction for Mexican immigrant youth in these rural, globalizing places. Entering the data via critical discourse analysis (Fairclough, 1995) and then utilizing Barton's (2003) "practice of science" perspective, with an eye toward achieving "radical contextuality" (Grossberg, 1997), we describe the science events, identities, and structures of the pig dissection lesson and detail how what these students could do with science, as rendered by that lesson, was limited by the roles the teacher attributed to the students, her inability to draw on their funds of knowledge as resources for learning, and the voice and position she allowed them to take up. The data reinforce conventional understandings of schools as sites of cultural reproduction (Bowels \& Gintis, 1976), as well as of resistance (Giroux, 1983), but afford us a glimpse of the particularity of those mechanisms within the demographicallytransitioning American Heartland, iconic of the era of global capitalism.
\end{abstract}

Keywords Mexican immigrant students · English Language Learners · Rural science education - Social and economic reproduction · Critical Discourse Analysis

K. Richardson Bruna $(\square)$

Iowa State University, E155 Lagomarcino Hall, Ames, IA 50011, USA

e-mail: krbruna@iastate.edu

R. Vann

Iowa State University, 335 Ross Hall, Ames, IA 50011, USA 
Mi hijo, es de, sí vas a ir a la escuela. ¿Sabes por qué? Porque aquí, en este país, si tú no sabes hablar inglés, no somos nada. No vamos a encontrar ningún parte de trabajo. Tú estás chico. Todaviá tienes tus estudios. Echale ganas y acuérdate bien, le dije. [My son, it's like, yes, you are going to go to school. Do you know why? Because here, in this country, if you don't know how to speak English, we aren't anything. We aren't going to find any work. You are young. You still have your studies. Work hard and pay attention, I told him.] (From an interview with Angela, whose son, Omar, 15, arrived from Petatán, Michoacán, México in 2004 to join his mother and his father, who works at the Bensen Meatpacking Plant, in Captainville, IA)

We've been talking about the body systems. I promised you that I was going to teach you how to dissect an animal. The animal that we are going to dissect are pigs ... because all of you guys keep saying, "Oh I can't wait to go down to Bensen so I can make money. (A teacher's introduction of a fetal pig dissection, from an observation of the "English Learner Science" class at Captainville High School)

Speed ... Work for speed! One cut! One cut! One cut for the skin; one cut for the meat. Get those pieces through! (A worker describing her foreman's urge for "line speed" at the plant (Human Rights Watch, 2004))

Meatpacking is big business. Increased dependence on immigrant low-wage labor coupled with emphasis on worker productivity, or "line speeds," has resulted in record industry profits. This economic prosperity, in the Midwest, is primarily due to the work of wage laborers from Mexico, whose common undocumented status ${ }^{1}$ puts them at risk of basic human rights violations. Noted abuses include lack of accurate record-keeping of hours worked, scant employee benefits, like health insurance (despite high rates of injury, especially related to repetitive stress), inadequate training (which results in injury), denial of bathroom breaks, and verbal harassment (Catholic Legal Immigration Network, Inc., 2000). Mexican workers are typically not familiar with U.S. law and, further, their non- or limited-English speaking status prevents them from easily gaining such familiarity. International law, in fact, entitles the undocumented worker to the same labor protections as lawfully employed workers (Human Rights Watch, 2004); however, fear of deportation makes them unlikely to call attention to violations. These individuals in the meatpacking industry are among the most vulnerable members of our work force. And their children are among the most vulnerable members of our school population.

The low academic achievement of Latino youth in U.S. schools is widely acknowledged (U.S. Census Bureau, 2004). Since two-thirds of the nation's Latinos are of Mexican origin and, of all Latino groups, it is these youth that report lowest aspirations for post-secondary education (Portes \& Rumbaut, 2001), as well as double-the-average national rates of leaving school (Ruiz de Velasco \& Fix, 2000), the educational experiences and outcomes of Mexican-descent youth in U.S. schools is already of national public policy interest. Their increasing presence in Midwest classrooms, however, is less well known but nonetheless merits examination if we are

\footnotetext{
${ }^{1}$ Of the one million immigrants who come from Mexico annually, a quarter is undocumented (Ruiz de Velasco \& Fix, 2000).

Springer
} 
to understand and respond to the challenges posed by the rapid ethnic diversification of the rural Heartland in the age of globalization. This requires that we problematize not only educational policy and instructional practice, but interrogate the very purpose of schooling for these youth.

The contemporary discourse of science education with underrepresented students revolves around the well-documented absence of cultural- and language-minority professionals in the science, technology, engineering, and mathematics (STEM) fields and the corollary need to increase participation (BEST, 2004a, b). Yet such initiatives rely on an unspoken assumption that the beneficiaries of the moreinclusive pedagogies will be "Americans" and that their improved education will facilitate technological and economic advances for the U.S. The transnational character of the population we are interested in here-families who are not seeking permanent affiliation with the host country for any reason other than economic support, and thus remain intensively connected to their communities of origin (Trueba, 2004, pp. 40-41) — challenges the multicultural discourse in science education. These students go up against tremendous odds: their parents have not typically received an education beyond the 6th-grade level, so support for education, as it is recognized by the school, may be limited in the home; the students themselves may have been out of school for several years before coming to the U.S., so significant knowledge gaps in the content areas may exist; they are likely to be longterm English Language Learners since they are being exposed to the target language at a later period in their life; and they are undocumented, so they are relegated to unstable, low-wage work opportunities as well as virtually shut out from state and federal loan programs that require documented status to dispense financial aid for post-secondary schooling. These are likely not the cultural- and linguistic-minority students that efforts to ameliorate the STEM crisis have in mind, yet these students exist in ever-increasing numbers, particularly in the Midwest.

The interaction of an aging population, declining birth rates, and failure of economic enterprise to retain college graduates, means that states, like Iowa, where our institution is located, are explicitly acknowledging their reliance on immigration for economic growth. The ability to teach these students well is not just a test of the multicultural discourse in science education but, larger still, it is a test of the U.S. schooling system's ability to understand its purpose in the age of globalization. As the opening quotes attest, Mexican immigrant parents understand very clearly the importance of education, as a vehicle of English language acquisition and future expanded job opportunities for their children, but science teachers may limit those experiences and opportunities by projecting upon Mexican immigrant youth the present economic arrangement. Indeed, since work at the plant is all about "line speed," what sense does science education make when the expectations for these students are that they will, as the quote from the foreman at the plant attests, just "get those pieces through"?

\section{Purpose}

Given this background, the purpose of our research is to describe the practice of science as we observed it in the education of high school Mexican immigrant youth in a Midwestern meatpacking community. This is a context we rarely see documented in the scholarship of science education. What has been reported (Zuniga et al., 2005) 
informs us, quantitatively, of systemic disparities in the placement and course-taking of Latinos and Whites; our research probes further, providing a qualitative account of the instructional practices that ensue as a result of such disparities. By taking the reader behind the proverbial "closed door" of one English Learner Science course in Captainville, IA, we beg the question,"How ready are science educators and science education researchers to plan and build science classrooms that are "spaces of hope" (Harvey, 2000) for all learners in U.S. schools?" Drawing on Harvey's work on insurgent architecture, we ask this question with a vision of teachers as "architects" in mind, for when the word "cities" is replaced by "classrooms" in the quote below, Harvey's words compel us to examine teacher practice as a reflection of both an individual [personal] and collective [political] imagination about the world we build and the people we build it with:

As we collectively produce our [classrooms], so we collectively produce ourselves. Projects concerning what we want our [classrooms] to be are, therefore, projects concerning human possibilities (p. 159).

\section{Plan for this paper}

In this spirit, we offer the following account of a teacher and students, situated within a particular school and community context, building together a particular practice of science reflective of a particular understanding of human possibilities. To develop the account, we begin by applying critical discourse analysis to a small, though pivotal, piece of the data-the teacher's explicit introduction of a pig dissection lesson as preparation for the students' work in the meatpacking plant. We do this analysis in order to provide a warrant for the cultural studies-based,"radically contextual" (Grossberg, 1997) approach we use to understand and examine the larger ethnographic data of the pig dissection lesson. We use the three-part perspective offered by Barton (2003) - that practices of science consist of science events, identities, and structures - as a heuristic to map and manage the ethnographic data, detail what each of these three elements looked like in the pig dissection lesson, and describe how, together, they achieved a particular practice of science with Mexican immigrant students in a Midwestern meatpacking community. We then conclude by problematizing that practice of science and pointing to lessons held by these data with respect to science education as a project of human possibility, science classrooms as spaces of hope, and teachers as architects of the social imagination. Returning to the pivotal piece of data that serves as the entry point for the entire account, we suggest the continued use of critical discourse analysis in multicultural science education research.

\section{Resignifying science: From an internalist to a standpoint stance}

Literally, invoking its Latin etymology, the word 'science' means "knowing." Science education, like all education endeavors, is deeply concerned with the production of "knowing." But, as Harding (1998) so famously asks, "Is science multicultural?" What capacity does science have to acknowledge the epistemological (waysof-knowing) resources of communities outside of its conventional purview? And, in 
failing to do so, how does science continue to relegate those communities to the margins of social and economic participation?

In asking these questions, Harding is critiquing science's internalist gaze, the way characteristic features-i.e., experimental or "scientific" method, standards of objectivity and rationality, etc. - are used both to define what science is and to insure its success. This gaze results in the conception that "science is singular-there is one and only one science-and its components are harmoniously integrated" (p. 2).

Harding is also critiquing whose science, whose "knowing," was the object of this internalist gaze. It was only the "mental abilities and talents, character, inquisitive and critical spirit, and political and cultural histories, institutions, and practices" (p. 28) of Europeans and European culture that were, as Harding explains, understood as being capable of or interested in adhering to the requirements of science's singularity, and, in this way, Harding continues, the rise of science is inextricably related to the rise of colonialism. Both were predicated upon a presumed biological and cultural inferiority of non-Europeans (and of women); and both created deeply entrenched "patterns of knowledge and ignorance" (p. 58). Harding summarizes the relationship between science and colonialism by elucidating basic aspects of their co-constitution. Essentially, her discussion points to how European science was oriented towards the establishment and maintenance of colonial enterprises, particularly in terms of increased profit and social control, and how European science systematically (though not necessarily intentionally) eradicated local science practices and traditions in ways that gave advantages to the colonial foothold (p. 44).

This latter point is important because it recognizes that scientific and technological traditions existed in non-European cultures: these cultures have engaged in cognitive and social activity resulting in systematic knowledge about the natural world around them. This activity and the ensuing knowledge are culturally specific, reflecting the physical and social environments in which they live, as well as the political interests of those in power. It is expressed though discursive resources, "cultural presuppositions, metaphors, models, and narrative structures" (p. 68) that reflect local knowledge, and is carried out through culturally specific forms of social organization. These are the basic "cognitive cores" of systematized knowledge production, shared with European science, yet, through the colonial project, nondominant people's engagement with this production has been relegated to "nonscience" status. Reviving and reclaiming the epistemological resources marginalized through European colonial science, as well as exposing the implications of continuing to privilege European, internalist ("modernist") conceptions of science is a fundamental motivation behind the critical and post-colonial impulse in science education. This impulse provides a counterpoint to the standards movement and its attendant high-stakes testing apparatus which together structure science schooling to benefit racial/ethnic-, class-, and language-dominant students, to occlude the social and political nature of science, and to restrict science's value to its technical features instead of its practical and progressive potential (Kyle, 2001, p. xii).

One way the critical and post-colonial impulse can be achieved is through what Harding calls "standpoint epistemology" (p. 149). Indebted to feminist theory, the use of standpoint epistemology in science and science education refers to the struggle to place marginalized concerns and populations at the center of scholarly inquiry and public political attention. From such re-centering, standpoint theorists argue, important knowledge resources are generated in the asking of new kinds of questions, questions, as Harding puts it, that arise from attention to "the lives of 'the 
weak"' (p. 154). In drawing attention to previously unrecognized issues and practices, light is shed on the world in which we live that has illuminating effects for everyone; thus, standpoint epistemology is not just "for" the marginalized. Because of its interest in pluralism and inclusion, as opposed to singularity and exclusion, standpoint epistemology is a way, as Harding asserts, to ensure "strong objectivity" and see, more fully than conventional approaches allow, the nature of the world we live in.

\section{Resignifying science education: From science for all to a practice of science}

In recent decades, we have seen multiculturalism addressed in science educationthrough calls, under the banner "Science For All" (AAAS, 1985), to make up for the disproportionate underrepresentation of women and people of color in the sciences. As Barton (2003) points out, however, these calls continue to bear the trace of the internalist gaze and its colonial effects through a deficiency orientation that is generated in three ways:

First, it is assumed that students who come to school not versed in the culture of Western science are 'lacking' and need to engage in extra efforts to catch up to their peers; Second; it is assumed that students will prioritize Western ways of knowing, without the backdrop of a culturally situated nature of science; Third, it is assumed that schools operate meritocratically, that scienceachievement scores are based on one's efforts and abilities rather than one's degree of enculturation into a system (p. 26).

Against the banner "Science for All," Barton juxtaposes, instead, an understanding of science as social practice. She seeks to emphasize "what people do with and in science" as opposed to, we could say, what science does with and in people; that is, she locates science learning in the processes of human subjectivity that are shaped by intersecting influences, influences which she refers to as science events, identities, and structures (2003, p. 37).

Understanding the intersecting influences that shape science learning subjectivity is essential for grasping the strategic advantage of a standpoint stance: (1) Barton defines science events with respect to what kind of science learning youth have opportunities to participate in. A standpoint stance requires that we theorize about these events - the activities, settings, artifacts, and associated knowledge, attitudes, and habits of mind-from the perspective of the youth's point of participation; (2) Science identities and relationships, for Barton, refers to students' shared and individual lived experiences; these are the values, beliefs, and cultural backgrounds that they bring with them into their participation in the science events (and which actually help construct the science event). A standpoint stance requires that we theorize about these identities and relationships - the interplay of voice and power-from the perspective of the youth's point of experience; and (3) Space and capital makeup what Barton calls science structures - the physical, human, and social environments in which science events and science are constructed. A standpoint stance requires that we theorize about these structures-the tools they provide-from the perspective of the youth's point of use (2003, pp. 36-42).

Standpoint epistemology, achieved through an understanding of science as social practice, compels us to look at the science classroom through a cultural lens and that Springer 
means accounting for the context that shapes a particular classroom culture. Therefore, what we intend to do in this paper is not simply situate a phenomenon in a context, but, alluding to Barton's framework, to map out the very events, identities, and structures, that bring the context into being (Slack, 1996, p. 125). "To put it another way," Slack writes, "the context is not something out there, within which practices occur or which influence the development of practices; rather, identities, practices and effects, generally, constitute the very context within which they are practices, identities, or effects" (p. 125). We are trying to make visible the "very conditions of the possibility of something," a goal which Grossberg (1997, p. 255) explains requires "radical contextuality".

\section{Background}

The location of our research is Captainville, IA. Over the last 10 years, $13 \%$ of Captainville residents have come to be Latino, the majority Mexican or of Mexican descent. This is because Bensen, a major meat-processing plant located in Captainville, attracts immigrant Mexicans to meet its demand for willing and inexpensive labor. As a result of a decade's demographic shift, Captainville schools are facing instructional challenges many other Iowa schools have not yet faced. Eighteen percent of the otherwise predominantly white $(77 \%)$ student body at Captainville High School is Latino, a figure nine times the state average. Of total enrollment, $13 \%$ are designated ELs (overwhelmingly from Spanish-speaking households). They help comprise more than half of the $38 \%$ of total enrollment that is on the free/ reduced lunch program at the school. The median income in the Captainville community is $\$ 36,000$. In 2003-2004, the achievement gap between white and Latino students increased at Captainville and was a noted area of concern for the district. Only $23 \%$ of Latino students, as opposed to $77 \%$ of white students, were assessed as proficient in reading comprehension. A similar gap existed for science proficiency as measured by the Iowa Test of Basic Skills (ITBS) (Captainville Community School District Annual Progress Report to the Community, 2003-2004).

The community and school are visibly very economically segregated. The low socio-economic-status neighborhood of small one- or two-bedroom homes surrounding the meatpacking plant (Photo 1) is referred to as "Little Mexico." As this name suggests, it is here that most Mexican, and poor white, families live. When the wind is just right, the whole area is saturated with the smell of pig flesh.

The economically-segregated nature of housing in the community is reflected in the ethnically- and linguistically-segregated nature of the middle school situation: for example, one middle school, right off of "Little Mexico," reports an enrollment of 125 English Language Learners, while the other, across town, reports only 44 (Captainville Community School District's Annual Progress Report to the Community, 2004). As a teacher at Captainville High explains, many students come to high school with a "white school vs. Hispanic school" mentality and it is there that they have to learn, for the first time, to "intermingle" (Richardson Bruna, Teacher Interview, December 20, 2005) (Photo 2).

Patterns of social relations among students demonstrate that this learning does not come easily. Mexican students report having ketchup packets thrown at them during lunchtime in the cafeteria while the staff does nothing about it (Richardson Bruna, Student Interview, May 17, 2005). White students talk about just keeping to 


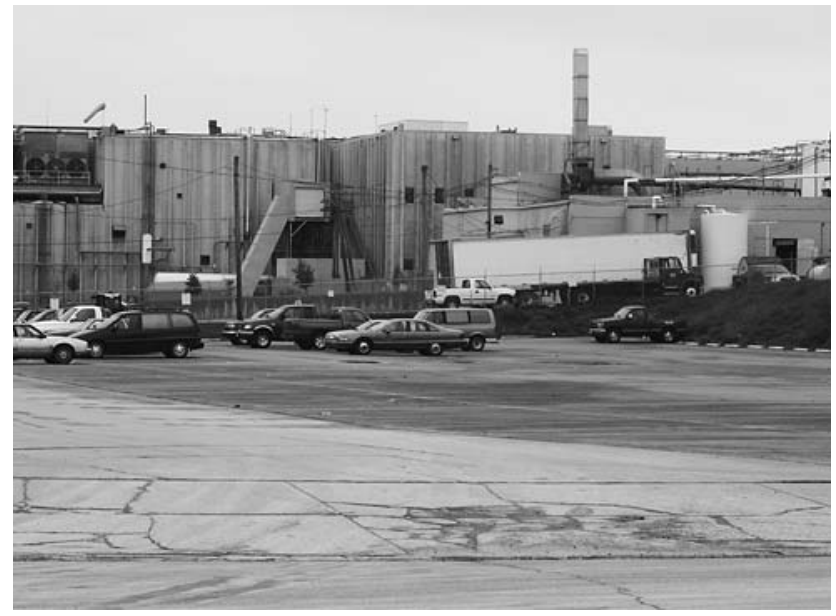

Photo 1 A view of the plant taken on May 1, 2006, the "Day Without Immigrants." Note the nearempty parking lot

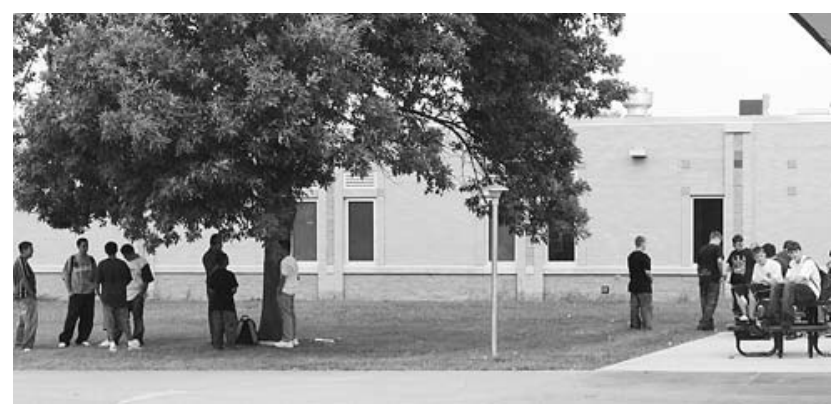

Photo 2 Students self-segregate as they gather outside at lunchtime. Latino youth congregate under the tree at left while white youth dominate the tables at right

themselves and really do not think racism is a big deal. They point to the Mexican students' liking to hang out together as evidence that they're not the ones who are racist (Richardson Bruna, Student Interview, March 3, 2006). But as the following quote makes clear, Mexican youth at the school are conscious of having to strike a balance between their desire to form friendship groups based on language, that shield them from American rejection, and their knowledge of the perception this can create of them in the eyes of Americans. When asked about the self-segregation observed among students in the cafeteria, Augusto, who will be a major actor in the account that follows, says:

Yo pienso . . porque ... bueno ... aquí como ya ve que uno llega .. y pues ya los americanos son sus amigos ... entonces a uno se le hace muy difícil trater de ... de de mezclarse con ellos ... porque en veces ellos sí ... uno siente rechazo de ellos ... entonces ya lo que trata uno es mejor de ... de . . mantenerse uno alejado pero no también tan distanciado porque ... después van a pensar que uno es el que no quiere ... tener amistad con ellos ... entonces ... nos sentamos 
así. [I think ... because ... well ... here like already you see that one comes ... and well already the Americans are their friends [friends with one another] ... so it makes it very difficult to try to ... to to mix with them ... because at times they, yes, one feels rejected by them ... so then what one tries is to better ... to ... to maintain oneself from afar but also not too distanced because ... later they are going to think that you are one that doesn't want ... to be friends with them ... so ... we sit like this.]

Augusto's observation of feeling "rejected" but having to be careful not to be "too distanced" to avoid creating a particular perception of himself illustrates how Mexican immigrant students, in learning to be Mexicans in the U.S., come to view themselves through the eyes of white peers and teachers. It is an astute explication of the processes of identity-making in motion. Importantly, these processes are not put on hold in the classroom environment, as we will make clear in our account of the research.

\section{Research design}

\section{Participants}

The participants in the pig dissection lesson that is central to our account were 15 students in the English Learner Science course at Captainville High School. They were approximately equally-split with respect to gender. All but two of those students (females from the Sudan) were Spanish-speakers from Mexico. They ranged in proficiency from non-English proficient to advancing fluency. Their teacher was a white female in her mid- to late-forties with a great deal of confidence and fluency, though not necessarily accuracy, in Spanish. One of the Mexican youth who plays a particularly active role in the pig dissection lesson is, as previously mentioned, a young man named Augusto. More information about Linda and Augusto will be provided as we return to examine more closely the participants in the English Learner Science course.

\section{Researchers' role and access}

We were introduced to the English Learner Science class when it was included as one of many other sites in our study of science teachers' approaches to academic language instruction in classes with ELs (Richardson Bruna et al., in press). The site caught our attention because of its English Learner designation-it was a site specifically designated for EL youth at Captainville - and also because of the interesting content-, language-, and personality-related dynamics of the teacher, Linda Crabtree, and her students. These dynamics are part of the context that we will be accounting for in the subsequent presentation of data.

One of us, Richardson Bruna, has continued her research activity at Captainville High School. She is doing an ethnographic case-based study of socioacademic identity formation of Mexican immigrant youth in science classes and is involved in professional development efforts to help one of the mainstream science teachers integrate language development objectives into his teaching. Her continuing involvement with this site, as well as her cultural studies- and critical educational 
ethnography-based identities, as will be explained below, informs the description, interpretation, and explanation contained in this account.

We do not carry "science educator" identities. Richardson Bruna is a multicultural education faculty with an interest in second language acquisition and Vann is an English/TESL faculty with an interest in cultural diversity. In line with our institution's focus on science and technology, and because of our research on the experiences of cultural- and language-minority youth in science education, we have both developed research activities related to enhancing equitable educational opportunities for all students in science. Given the rapidly-changing demographics in Iowa and throughout the Midwest, specifically due to the globalizing agri-foods industry, we believe an examination of science education with Mexican immigrant youth in these changing communities highlights the kind of processes likely to characterize schooling in these periods and places of transition. These processes deserve attention if the educational scholarly community is going to understand the local effects of globalization, particularly on schooling.

While globalization is most commonly understood in terms of its economic aspect, the internationalization of production and the accompanying movement of capital (including human capital) from one national sphere to another, globalization also entails a social aspect. Amidst the globalizing economic processes emerge new social processes in which individuals engage in and with ways of being and behaving that cross not only geographic and political borders, but cultural and linguistic ones as well. The new social fields generated by such crossing are constructed out of "intricate webs" of new kinds of relationships (Goldin, 1999, p. 1). For the immigrants, these include the relational processes involved in "becoming other" with respect to both the culture of origin and the host culture. Teachers of new immigrants, albeit often unknowingly, play an integral role in these processes by being among these students' first point of contact with an institutionalized racial/ethnic, linguistic, and economic "other" identity in the receiving communities. Preparing professionals to meet the needs of all education-related constituencies-teachers, families, students - in these receiving communities requires understanding the context in which the "intricate webs" of new kinds of relationships are woven.

Our interest in achieving radical contextuality in this paper aligns well with the field of cultural studies. As a cultural studies-inspired work, we are not interested in setting forth an ultimately positivistic rendering of events, but rather engaging in the theory and method of articulation. As Slack explains, the theory and method of articulation were originally described by Laclau (1977) as a response to reductionism. "Simply put," she explains, "[Laclau found that] not everyone believes what they are supposed to believe or acts in a way they are supposed to act" (p. 118). So Laclau rejected reductionist accounts of the social and political landscape by asserting that "(a) there are no necessary links between concepts, a move that renders all links essentially connotative, and (b) concepts do not necessarily have links with all others, a move that makes it impossible to construct the totality of a system" (p. 119). Thus, research can never discover the "reality" of any object of study; all it can do is theorize how social forces exist, with respect to an object of study, in complex relations with one another by "articulating" (making connotative, never ultimately denotative, connections among) those relations (p. 121). Because the rigor of articulation rests in its capacity to contextualize, our interest in radical contextuality should not be seen merely as a preference for the descriptive, but as a substantive part of our overall theory and method.

Springer 
In addition to being a work in the cultural studies style, this paper is, as previously mentioned, part of a larger project of educational ethnography. Ethnographers of education go about the work of understanding schooling as a "calculated intervention" into the learning process of an individual with (intended or unintended) outcomes (Spindler \& Spindler, 1987). They engage in extensive, long-term collection of data that attest to the culture of the "calculated intervention" from the points of view of some or all of the participants involved. Schooling, in educational ethnography, is understood to be part of a society's interest in cultural transmission- the passing on from one generation to the next of a body of knowledge, attitudes, beliefs, and behaviors, often understood as that society's "core" or "common" culture (Spindler \& Spindler, 1990). Critical educational ethnographies, of which this work is a part, adopt the cultural studies perspective that culture cannot be theorized from a point-of-reception ("transmission") perspective and are thus interested in the transactions and conflicts that arise when the "core" or "common" body of knowledge, attitudes, beliefs, and behaviors comes under explicit or implicit dispute in the schooling context. This is likely to be the case, of course, when a school begins to serve populations whose wants and needs it has previously never had to consider. Captainville High was one such school.

\section{Data sources}

The primary data reported on here were collected in late April of 2004. They were gathered through videotaped classroom observations of 3 days of a week-long pig dissection lesson in the English Learner Science classroom at Captainville High School. These videotapes were transcribed and then the transcripts reviewed and broadly coded with an eye toward identifying features of the pig dissection lesson that mapped against Barton's (2003) practice of science perspective: science events, identities, and structures. Also at this stage in the procedures, Linda Crabtree's initial and explicit framing of the pig lesson as preparation for work in the meatpacking plant was identified as a critical incident (Fairclough, 1995). It served as a warrant to examine power relations in the setting and, as such, was subjected to critical discourse analysis (CDA) (Fairclough, 1995) in order to examine what it revealed about how people understand their social position, and, importantly, use language as a form of social action to reproduce or resist that position.

\section{Data analysis}

In accordance with critical discourse analysis, we described the critical incident at what Fairclough calls an "immediate" level; that is, we analyzed the linguistic aspects of its text. Then, we interpreted the critical incident at the "institutional" level and explored how it represented particular institutionalized statuses of the participants. Finally, we explained the critical incident at the "societal" level, seeking to determine how the institutionalized statuses of the participants reflected larger social narratives about their subject positions (Fairclough, 1995, pp. 25-27).

Our CDA-based analysis of the critical incident served as our "entry point" into understanding the larger data set and was the reference by which we viewed the other data as either convergent or divergent in terms of interpretation. Fairclough alerts us to the fact that sites of divergence in the data, which he calls "cruces," can be productive places of tension that notify us of gaps in our theories that deserve 
tending. As we reviewed the coded data of the pig dissection lesson that mapped against each of the features of Barton's practice of science perspective, we read these data against the "meanings" (articulations) produced by the CDA-based analysis of the critical incident. Our ultimate purpose in applying these procedures was to articulate the "very conditions of the possibility" (Grossberg, 1997) of the critical incident and to trace the power relations, borne out in the immediate-, institutional-, and societal-domain-based reading of the critical incident, as they construct a particular practice of science with Mexican immigrant youth in this community.

Lastly, to draw out the ethnographic context, some secondary data sources, such as teacher and student interviews, as well as descriptive background information gleaned from Richardson Bruna's longer-term involvement with this setting, were used to supplement the account.

\section{Introduction to the results}

We report on the results of our analysis in two parts. The first part focuses on the findings produced by our application of critical discourse analysis to the focal critical incident - the English Learner Science teacher's framing of the pig dissection lesson, on the first day of the activity, as preparation for her Mexican immigrant students' work at the local meatpacking plant. The second part focuses on the findings produced by our application of Barton's practice of science perspective to the 3-day'sworth of videotaped observation data from the pig dissection activity. Our report on the critical discourse analysis findings in the first part of this results section is intended to make visible the different social actions performed by the teacher's framing and to detail how those are realized through particular linguistic choices (Halliday, 1989; 1994). Then, in the second part of the results section, we are interested in describing how these social actions achieve a particular practice of science in the English Learner Science course, one that explains "the very condition of the possibility" of the teacher's initial pig-dissection-as-meatpacking-prep analogy. In presenting our results this way, we are operating from a theory of language as social practice viewpoint; that is, we are trying to represent the idea of the coconstitution of language and social context. As Fairclough (1995) states:

Linguistic phenomena are social in the sense that whenever people speak or listen or write or read, they do so in ways which are determined socially and have social effects ... Social phenomena are linguistic, on the other hand, in the sense that the language activity which goes on in social contexts (as all language activity does) is not merely a reflection or expression of social processes and practices, it is a part of those processes and practices (p. 23, italics original).

We present the results in two parts in order to capture the co-constitution, in the English Learner Science classroom, of the social context and its linguistic realizations.

\section{Part 1: The critical incident and its analysis}

In this part of the paper, we begin by simply sharing the critical incident that served as an entry and reference point throughout our examination of the larger data-how 
Linda Crabtree explicitly framed the pig dissection lesson as preparation for students' future work at the local meatpacking plant. We then analyze the text of this incident using critical discourse analysis.

The critical incident happens within the first minute of the first of the three videotaped observations of the pig dissection lesson. Linda is standing at the front and center of the classroom with her hands folded on top of a tall, slender case containing a preserved fetal pig, that is on the table in front of her. Students' desks are lined up in two rows on each side of her table. These run perpendicular to her so that, although students are not directly facing her, they are directly facing each other. Linda asks the students to bring themselves closer (occupy the seats closest to her) and quiets them for the official beginning of class. While some students are still getting settled, she says:

1. We have been . talking ... shhh ... nosotros antes hablar los sistemas de la

2. cuerpo ${ }^{2}$ we've been talking about the body system . and then we took a break

3. and we started working on some rocks . I PROmised you ... that I was going

4. to teach you how to DISsect ... an animal ... the animal that we are going to

5. DISsect ... are pigs . because all of you guys keep saying. oh I can't wait to

6. go down to Bensen . so I can make money . well if you're gonna learn about a

7. PIG before you go to work at Benson. we're gonna start talking about a pig.

8. and we're going to start talking about what is inside of a pig . this is what

9. YOU are going to be doing.

The immediate level of analysis

In terms of describing the most immediate, linguistic, level of analysis, several elements in this excerpt are especially noteworthy: Most basically, there is repetition of the word 'dissect' (in lines 4 and 5) and particularly of the word 'pig.' (in lines 5, 7, and 8). Moreover, there is stress on the word 'promised' (in line 3), 'dissect' (in lines 4 and 5), and 'you' (in line 9). There is a shift in the use pronouns: 'we' (in lines 1-3) to'I' (in lines 3-4), back to 'we' (in line 4), to 'you' (in line 5), back to 'I'(in lines 56), back to 'you' (in lines 6-7), back to 'we' (in lines 7-8), and finally back to 'you' (in line 9). There is also a shift in tense: from past tense (in lines 1-3) to future tense (in lines 3-9). There is use of markers of logical relationships in line 5 ('because') and line 6 ('if'). Additionally, all the lines of the text are declarative statements. As we explain below, these linguistic choices both speak to and help realize contextual variables at work in Linda's English Learner Science classroom.

\section{Repetition and stress}

Linda's use of repetition and stress mark the key ideas of the context. The lexical items that are repeated are 'dissect' and 'pig,' signaling that the central focus is the pig dissection. Stress underscores some of these repeated terms and highlights others, such as 'promise.' Significantly, the pig dissection is textually linked to a promise Linda made to her students. The stress she gives the word 'promise,' as she also stresses 'dissect' and 'pig,' creates an ideational linkage between these three terms that is central to all of the discussion that follows. Since one of Linda's goals was to

\footnotetext{
${ }^{2}$ Here and throughout this paper, errors in Linda's Spanish have not been corrected.
} 
teach academic language, we can also understand Linda's choice of stress placement as a way of marking terms she wanted the students to learn. This established a particular relationship with students, with respect to these words, that we talk about again later.

\section{Pronouns}

Linda's shift in pronouns realizes her positionality in the context. When she is reviewing what the class has been doing up until the pig dissection lesson, she uses 'we,' indicating a collective classroom identity. Her positionality shifts to ' $\mathbf{I}$ ' in line 3, however, as she introduces what she is now going to teach the class ("I PROmised you ... that I was going to teach you how to DISsect"), signaling her more singular teacher identity. This briefly changes back to 'we' ("the animal that we are going to DISsect") to emphasize again the collective nature of participation in the lesson, before changing to 'you' in lines 5-7 ("all of you guys keep saying . oh I can't wait to go down to Bensen . so I can make money . well if you're gonna learn about a PIG before you go to work at Benson'"). This shift to 'you' emphasizes a separation from Linda's inclusion in the pig dissection activity to her exclusion from the reason they are doing the pig dissection activity ("all of you guys keep saying"). Her revoicing of what the students said about going to work at the plant ("I can't wait to go down to Bensen . so I can make money") further underscores this separation between Linda and her students as, in taking up their voice, she is demarcating that it is not her voice. She makes clear, through her use of pronouns in lines 7-9, that it is the students who will be doing the learning ("well if you're gonna learn about a PIG") and it is the students who will go to work at the plant ("before you go to work at Benson"). But, in the class, the work of doing the pig dissection that involves talking about the pig dissection ("we're gonna start talking about a pig and we're going to start talking about what is inside of a pig") is a collective undertaking. Given that she has set up the pig dissection lesson as collective work in opposition to the students' reasons for wanting to do the pig dissection (which she sets apart from her own subjectivity), it is interesting that she shifts back to the use of the pronoun 'you' in the final line when she is talking about the activity of the pig dissection lesson ("this is what YOU are going to be doing). This may indicate that Linda's previous use of 'we' to indicate a shared subjectivity with the students is suspect, i.e., rhetorical, as, ultimately, and, notably, with stress, she ends her framing by stating it is the students who are doing the dissection.

\section{Verbs}

The verbs Linda chooses to use also help us understand this context. Up to line 3, the ideas she is talking about are framed in the past tense. Specifically, she is talking about the previous work they have done in the class, on body systems and on rocks. Also framed in the past is a promise she has made to the students ("I promised you that I was going to teach you how to DISsect ... an animal). There is a shift to the future tense, however, in line 3 ("the animal that we are going to DISsect) that informs us of the near immediacy of the pig dissection. This shift to the future tense, in lines 6-9, continues to frame the students' learning about a pig as something that is about to take place ("you're gonna learn about a PIG,". "we're gonna start talking about a pig and we're going to start talking about what is inside of a pig . this is what 
YOU are going to be doing"), pointing to the fact that dissection activity of the pig dissection lesson will begin in earnest on the next school day. These tense shifts achieve the instructional purpose of this statement as a review and preview of course content and help explain Linda's shift from a 'we' sensibility in the beginning of her framing of the pig dissection to a 'you' framing at the end; she is engaged in teacher talk, trying to connect future and past learning, and her use of 'you' in "this is what YOU are going to be doing" is a clear signal and summary of that teacher position.

\section{Logical connectors}

Linda's use of logical connectors 'because' (line 5) and 'if' (line 6) further provide contextual information. Her use of 'because' in 'because all of you guys keep saying . oh I can't wait to go down to Bensen . so I can make money" signals the way she understands her promise to them; she has promised them the pig dissection because they have told her they want to work in the plant. This achieves not only the justification for doing the pig dissection lesson-it is something the students have asked for-but also justifies her framing of the pig dissection in relationship to work at the plant. Likewise, her use of 'if' to signal a hypothetical condition in line 6 ("well if you're gonna learn about a PIG before you go to work at Benson"') also serves as a type of justification for the lesson itself and her framing. What is framed hypothetically isn't whether the students will work at the plant, it is whether they will learn about a pig before they do so. Linda's choices seem to reveal the idea that she could have had the students do the pig dissection on any animal, but, because of their futures at the plant, she has decided to have them dissect pigs (as opposed to another animal). They position her as a teacher who is doing her students a special favor which cues a particular relationship with her students that we will describe in more detail later.

\section{Declarative sentences}

A basic way that Linda constitutes the tone of the text is through her use of a series of declarative sentences. She is constructing her relationship to the students as someone who is telling them, quite simply, the way things are; in other words, she is performing her teacher role in a specific way here as she explicates the context. She is also, in marking some words with special stress, performing a specific feature of that teacher role, which is to teach academic language to these English Learner students. Students, through this positioning, are put in a passive listening role and, beyond that, their identities as non- or limited-English proficient students, and hers, as their teacher, are marked.

\section{Cohesion and thematic organization}

Linda's cohesive and thematic choices provide some final contextual information. The parallelism of the use of past tense in the clauses up to line 3 and the similar parallelism of the use of the future (constructed by "going to") in subsequent clauses creates a recognizable school text centered on, as previously pointed out, review and preview. Additionally, the thematic organization of the text, with its reference (in line 2) to body systems, to dissecting an animal (in lines 4 and 5), and to learning about what is inside (i.e., the body systems of) a pig (in lines 8), produces the "main 
idea" that the pig dissection activity is an application of their previous study of body systems. This thematic organization inherently links the pig dissection to the science curriculum, thus positioning the students as science learners. Embedded in this, however, is the other inherent positioning - that of the students as non-science professionals-achieved through her referencing of their work as future meatpackers at the local plant.

It is possible to observe how Linda and her students perform the context represented by all of these local linguistic choices in the upcoming ethnographic account.

The institutional level of analysis

In terms of explaining the institutional level of analysis, there are two Discourses, or institutionalized ways of thinking, believing, and behaving (Gee, 1996, 1999), that were operating in Linda's framing of the pig dissection. The first is Teacher Discourse; Linda drew on the Teacher Discourse in her construction of a text that served, in its "official" capacity, as a review/preview of instruction, including the pre-teaching of key lesson vocabulary. The second Discourse is Economic Discourse. Unlike the more universalized Teacher Discourse that we can imagine seeing enacted in classrooms across the country, this Discourse is peculiar to this specific school and community context. Linda drew on the Economic Discourse of meatpacking, in an "unofficial" capacity, to relate the pig dissection lesson to students' work at the plant. What interests us is Linda's invocation of a third mediating Discourse, an Affective Discourse, to bridge these Teacher and Economic frames. Linda invokes this Discourse when she states, in her framing of the lesson as preparation for work in the plant, that she is fulfilling a "promise" to the students. This mediating Affective Discourse signals a particular relational context operating in the English Learner Science setting. The ethnographic data describe this relational context in further detail.

The societal level of analysis

The final level of analysis is the societal. It is here that we can attend to larger power structures, such as those that underlie the globalizing movement of human capital, and interpret how and why they manifested themselves in the immediate and institutional levels of Linda's discourse.

Clearly, Mexicans who labor in meatpacking plants, particularly the undocumented, are not privileged by these societal power structures. As set forth in the introduction to this paper, these individuals are among the most vulnerable in the U.S. What gives these families hope, however, is that by coming to the U.S. and working in the plant, they are achieving a future for their children. Sending their children to school, where they will learn the most valued commodity-English—is an integral part of creating this future. And, with English, it is hoped that other kinds of work will become available for their children. These families send their children to school not to be taught to work at the plant, but in hopes that they won't have to. Instead, in the English Learner Science classroom at Captainville High, a place that would seem to hold the potential to provide for these students two valuable assets, an English and science education, the ethnographic data will reveal how easy it is for the economic power structures to reproduce themselves (Bowles \& Gintis, 1976), even to the extent that the teacher's framing of the pig dissection as preparation for work at the plant is justified as something called for by the students themselves.

Springer 
With respect to our interest in understanding the "conditions of the very possibility" (Grossberg, 1997) of this framing of the pig dissection lesson, larger social, economic, political, and historical forces, and their manifestation in school and community practices of this particular community, are clearly at play. In the next part of the results section, we examine those practices through a three-part series of articulations that explores the practice of science simultaneously represented and constructed by this critical incident, Linda's framing. We use Barton's (2003) interrelated features in order to ground the critical incident in a particular set of science events, as reflective and constitutive of a particular set of identities, and reproductive of a particular structure in this particular classroom, school, community, and in U.S. society.

\section{Part 2: The practice of science $\&$ its articulations}

In the second part of this results section, we document, using Barton's (2003) perspective, the practice of science represented by and reproduced through the critical incident. We create our account through a series of three articulations, each corresponding to one of the features of Barton's practice of science perspective.

Articulation 1: the pig-dissection as science event

Following Barton (2003), in this section, we will describe the pig dissection as a science-learning event; that is, as an activity taking place in a particular setting with particular participants, using or producing particular "artifacts" or tools, that is predicated upon particular desired learning objectives ("knowledge, attitudes, habits of mind") achieved through the social interaction of the students and teachers involved (pp. 36-38). Some of the information presented here will foreshadow discussion to be taken up in greater detail in the subsequent Science Identities and Science Structures sections.

\section{Event parameters}

\section{Setting}

The English Learner Science course at Captainville High School, as the course's name suggests, was intended for students who were non- or limited-proficient English speakers. As the teacher, Linda Crabtree, described it, the course was meant to prepare students for their placement in mainstream science courses the following year, and, because of this, one of the main purposes of the segregated setting was to develop specialized vocabulary in science. While many students in the course were new arrivals and non- and limited-English-proficient, this was not the case for all students, as will be seen later.

The classroom itself was located in a new "EL Wing" just off of the school's cafeteria. As a new addition to the building, the classroom had adequate lighting and clean floors. The classroom contained approximately 20 movable seat-desks with writing tables, two whiteboards, one TV/VCR mounted on the ceiling, and a flank of five computers against one wall. The classroom was decorated in a "multicultural" motif with Mexican sombreros hung above the white board at the front of the classroom, two flags—one Mexican and one Canadian—hung on the whiteboard at 
the side of the classroom, and a poster stating "We are all Americans" hanging over the interior side of the classroom entrance. Because the classroom was used for other EL courses, like EL Math, and EL American History, it did not house the equipment typically expected in science classrooms. Notably, with respect to the pig dissection activity, there were no sinks and lab tables.

\section{Participants}

As the teacher of the pig dissection lesson, Linda Crabtree was a major participant. She moved to the community 11 years ago after having taught 11 years previously in another (non-EL) context. Her professional training as a teacher did not necessarily prepare her for work in an EL science context. Importantly, she was neither trained in the content area of science at the secondary level nor in work with bilingual or ESL populations. As she put it, she's taken "some courses" on instructional strategies for ELs. Despite this lack of a specialized background, Linda has been involved in developing EL programming for the high school.

Even though Spanish was not the native language of all of her students and that her own Spanish was limited, Linda taught the class bilingually in order to facilitate communication with her students. She did not have a particular bilingual education model that guided her instruction, but rather randomly switched between her Spanish and English as determined by particular interactions with her students and her instructional goals. It was Linda's Spanish, which she learned teaching English in the mountains of Peru on a church trip, that got her the job at Captainville. She was regarded as a proficient Spanish speaker by the non-Spanish-speaking administration and faculty (which made up all of the school except for two Latina bilingual aids) and, because of this, her class time was routinely interrupted with calls being put through by secretaries to translate for parent communication. Because of her Spanish, Linda was well-loved by her students. She was the liaison between them, their families, and the school, a role they clearly appreciated. She frequently touched and hugged her students as well as engaging in other forms of affection, such as humor (at both her and her students' expense). Linda embodied the "kind-hearted teacher" role in acting on behalf of the segment of the population that other teachers at the school were unprepared and unwilling to teach.

There were 15 students in Linda's class. The majority of these participated relatively passively in the pig dissection lesson, doing what Linda asked them to do, but not engaging in much direct conversation with her or their peers about the science ideas that Linda was trying to teach in the lesson. A notable exception was Augusto.

First of all, Augusto had spent time en la prepa, in a college-preparatory high school, in Mexico. This meant he had higher levels of Spanish language and literacy than many of his peers. Second, he had taken the English Learner Science course with Linda 3 years ago, as a freshman. This meant he was not a newcomer to American culture and the English language. Sometime between his freshman year and his senior year, when these data were collected, Augusto and his father returned to Mexico. At this time, as Augusto recounts, Linda called and endeared herself to him and became, as he describes it, like his second mother (Y me fuí a México ... y allá me llamaba ella y yo ... me encariñe mucho pues con ella ... es como mi segunda mamá vamos a decir. [I went to Mexico and she called me there and I came to care a lot for her ... she is like my second mother, let's say]). Augusto and his father eventually returned to Captainville and Augusto enrolled again in Linda's course. 
Importantly, Augusto wanted to study agriculture and return to Mexico. He said, "Bueno a mí deside chiquito me ha gustado ... trabajar con animals todo eso ... la tierra ... todo eso entonces yo ... me gusta poner atención porque pues ... pienso que el en futuro puedo poner en práctica ... todo lo que he aprendido [Well ever since I was little I have liked working with animals, all of this, the land ... all of it so ... I would like to pay attention because ... I think in the future I can put it in practice]. Because of Augusto's educational background, previous experience at Captainville High, and desire to learn, he viewed himself as different than his peers. He was not a newcomer but he was also not like some of the other non-newcomer youth in the course, whom he regarded as troublemakers:

Como esos otros muchachos que han estado en otros lados ya piensan que ... que ya saben más o menos para hablarlo ... para hablarlo aquí y así ya no ponen mucha atención . . pero estos muchachos que vienen de México ... como que le echan más ganas ... porque yo creo que acá sus papas les dicen que ... que tienen que aprender inglés que para eso vienen o algo ... y eso es a lo que ellos ... realmente vienen es al inglés ... Siempre le estábamos poniendo atención a la maestra ... En cambio todos estos muchachos que entraron nuevos ... como que vienen más relajo de allá de ... de las otras escuelas y ya ... no ponen tanta atención ... La mayoría acaban de llegar ... uno que otro son muchachos que no tienen muy buen aprovechamiento en otras clases regulares ... en inglés ... y los mandan aquí. [Like these other kids that have been in other parts [of the U.S.], they already think that, that they already know more or less how to speak it [English] ... to speak it here and because of this they don't pay much attention ... but these kids that come from Mexico ... like they have more drive ... because I believe that there their parents told them that ... that they have to learn English, that for that reason they come or something ... and that is really what they ... really they come for the English ... They always were paying attention to the teacher ... In contrast, all these kids that came a few years ago, it's like they come more relaxed from there, from the other schools ... and they don't pay that much attention ... The majority just came ... some are kids that don't have very good behavior in other regular classes ... the ones in English ... and they send them here.]

Augusto's description of some of his peers' background and behavior in this quote suggests that, despite all being placed together as "English Learners" in the English Learner Science course, there was great variation among the students. According to Augusto, students differed from each other with respect to length of residency in the U.S., proficiency in English, and motivation to learn. This quote also informs our understanding of the English Learner Science class as a potentially disciplining place, a setting where other teachers could send students they didn't want in their mainstream courses.

\section{Activities}

The pig dissection activity spanned the course of one week, although we have data only from the introductory Friday, the first day, Monday, and the last day, the following Friday. On the first day, the first Friday, the pig dissection activity involved reviewing the human body systems, looking at a handout of a pig's body systems, and identifying the body systems of a fetal pig preserved in a glass case. The second day, 
Monday, involved cutting open the pigs and tying their front and back legs apart so there was easier viewing of the internal organs. The last day of the pig dissection activity, the following Friday, consisted of students cutting out both the large and small intestines, measuring them in millimeters to determine the age of the fetal pig, and writing those measurements on the white board at the front of the room.

\section{Artifacts}

The pig dissection activity required a number of tools to be used in the classroom, namely dissecting trays lined with paper towels, "scalpels" (which were, apparently, a random assortment of Linda's own knives, including steak and hunting knives) (Photo 3), tweezers, and, of course, the preserved fetal pigs. Students were given packets that contained directions for the pig dissection (in English) and had access to a limited number of rulers for measuring the pigs' intestines.

Students' knowledge and learning

\section{Knowledge}

In addition to the framing of the pig dissection lesson as producing knowledge of a pig's body systems that would be relevant to the students' future work at the meatpacking plant, Linda expressed other desired knowledge outcomes of the pig dissection. One of these was with respect to next year's Biology class. This framing came within approximately five minutes of the first meatpacking framing. Linda says:

What I want you to do because this is from Mr. Fred, excuse me, Mr. Frank ... Mr. Frank is the Biology teacher that many of you guys will have next year ... Mr. Frank has borrow has given this to us ... so that you can locate some of the organs ... that are in our body compared to the organs . . inside the fetal pig ...

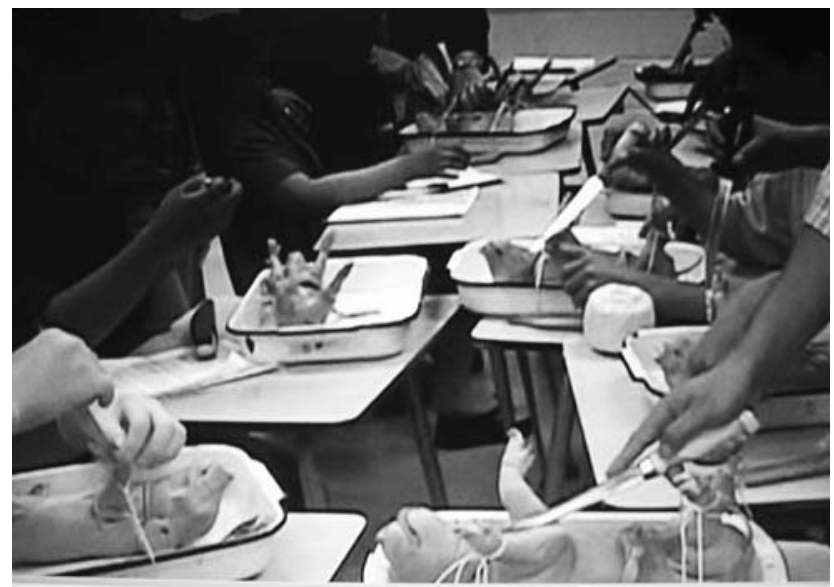

Photo 3 Students were given a random assortment of knives, including steak and hunting knives, to do the pig dissection

Springer 
Just a few more minutes into the transcript, as Linda is explaining the tools they will use, Linda likens the dissection activity to the work of a doctor performing an operation:

The pigs that we'll be working on ... are going to be small pigs . . like this ... we'll be working on them .. in a tray ... just like a doctor ... igual un doctor.

Another frame that was inherent in the course, because it was an "English Learner" course, was the knowledge objective of language development. Linda tried to achieve this knowledge-related goal in a variety of ways in her instruction. Usually she achieved this through slowed speech, emphasized words, repetition, and direct instruction (signaling a word as academic language by verbal prompts such as "what does that word mean?" and/or by writing the word on the board) (Richardson Bruna et al., in press). The following example shows what this language-knowledge goal looked like when Linda used the technique of repetition.

On the first day, in response to a student's comment that he had dissected a rabbit in Mexico, Linda asks the students whether rabbits and pigs have the same internal organs. Augusto shares the observation that some animals must have different organs than others because some regurgitate their food (Photo 4).

Linda draws on Augusto's answer when she asks Rosa:

Linda: Rosa, what is it called when the food is brought back up from the stomach ... cómo se llama?... re ... everybody ... re

Students: re

Linda: gur

Students: gur

Linda: gi

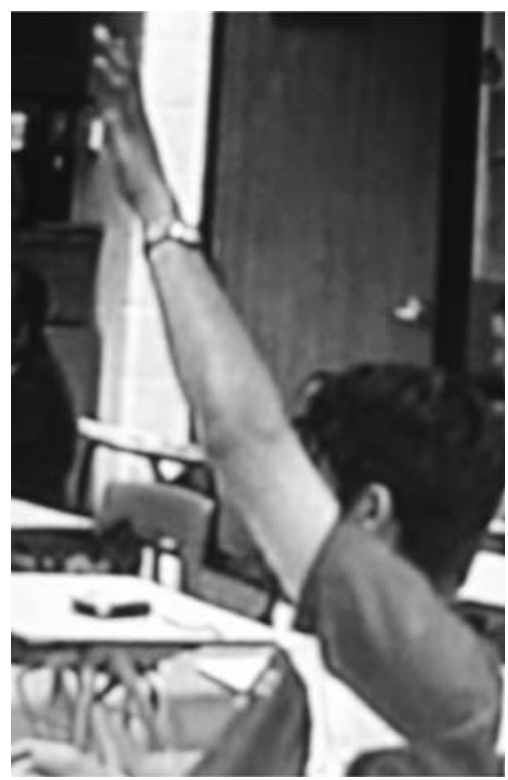

Photo 4 Augusto volunteers his answer to Linda's question about whether pigs and rabbits have the same internal structure 
Students: gi

Linda: tation

Students: tation

Linda: regurgitation

Students: regurgitation

Linda: That's what they throw up (mimes throwing up) vómito . regurgitation

In addition to Linda's knowledge goals, students brought their own background knowledge to the pig dissection lesson. The following examples showcase the ways students inserted their background knowledge into the lesson and illustrate Linda's way of responding.

The first example is from the first day of the pig dissection activity. Linda is still standing front and center and referring to the glass-encased fetal pig. She's wanting to draw students' attention to body parts on the fetal pig as a way of getting them interested in the activity. Notice how Augusto inserts his reference to Mexico, which highlights the knowledge he brings into the course about pigs:

Linda: OK ... and if you look at this ... pig ... you can see where its ... where on a person would be its fingers ... down here ... there is its intestine

Augusto: But you wait ... when you saw them coming ... because I used to work a lot with those animals ... in Mexico ... when you saw them coming they had like protections in their nails

Linda: Uh huh

Augusto: They had like ... little gums or something

T: Uhu

Augusto: And when they start walking those go away and they they just have the Linda: they make it the claws like ... the hoofs ... so what I want you to do is I want you to take turns ... looking at the books ... here are some more books

A little later on the first day of the pig dissection lesson, August tries again:

Linda: You'll have a tray una tray this is called a dissecting tray (draws a tray on the board then writes the word) it will be big enough shh excuse me it will be big enough so that the pig will lay in it so you will all need a dissecting tray

Augusto: I used to work with that kind of trays but in you know like in a in la prepa Linda: Uh huh

Augusto: the high school in Mexico ... and we opened hearts

Linda: Yes ... we'll also be using dissecting pins

And still later on that first day he tries yet again (Photo 5):

Linda: because we're going to determine how old the fetal pig was ... we can use the information from the pig ... to decide if it was twenty-one days, seventy-two days Augusto: pigs how long uh

Linda: What is the gestation for pigs?

Augusto: I think it's three months and twenty-one days or something like Linda: Pigs' gestation is not very long

Augusto: Because with my when I was like in Mexico with my female pigs

Augusto: I used to count three months and twenty-one days ... and I said OK it was the day when the piggies got pregnant for this month they're gonna have their babies Linda: OK. So by looking at the size of the pigs we can determine how old 


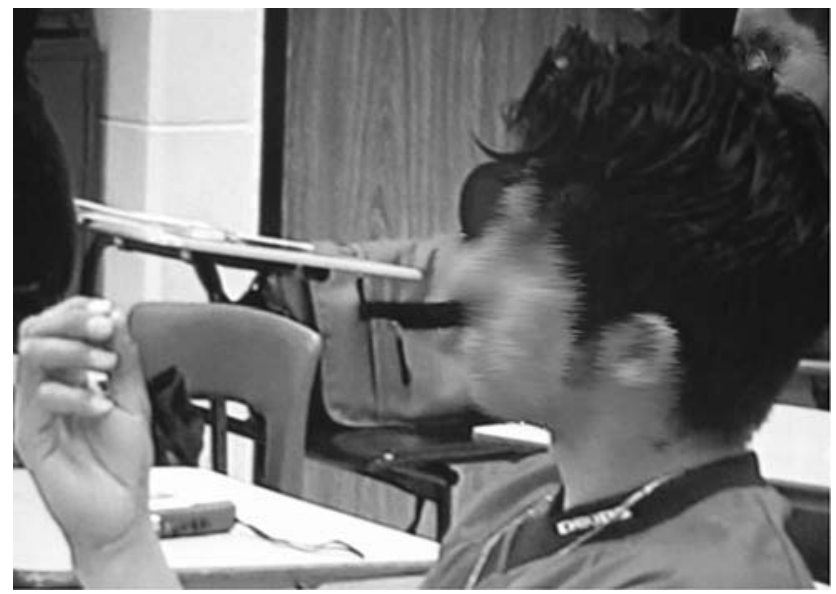

Photo 5 Augusto discussing what he knows about baby pigs' "nails" from his farm life in Mexico

In all of these examples, Augusto is inserting knowledge from his life back in Mexico into Linda's discussion of the pig dissection lesson (and notably not receiving much take-up from Linda). However, there were times in the lesson when students' contributions regarding their background knowledge would get taken up in a way that altered where Linda was going with the lesson. In the following excerpt, Linda, in asking whether Mario will be in class on Monday, finds out that he dissected rabbits in Mexico. She uses this information to re-highlight one of her purposes of the lesson-body systems:

Linda: Mario, are you gonna be here on Monday? (Mario nods.) You're going to use your scalpel? (He nods again.) Cut your pig? (He nods again) How are going to dissect?

Mario: Le parto la cabeza en cuatro (mimes action) [I'm going to cut the head in four]

Linda: I don't think so (Mario nods) How are you gonna dissect?

Mario: (mimes cutting something while saying something inaudible; from the context we assume he was talking about having dissected rabbits in Mexico)

Linda: Like the rabbit? (Mario nods) Do you think a rabbit has the same as a pig?

This leads to discussion between Linda, Julian, Mario, and Ramiro about whether rabbits and pigs have the same insides. Then Linda turns to the full group and continues:

Linda: Mario brought up ... and I wanna ask all of you quiero hacer una pregunta yo quiero preguntar este con todo Uds. Mario dice cuando el está en México ... when he was in Mexico ... he dissected a

Ana: a rabbit

Linda: is a rabbit ... going to give you ... the same internal structure as a pig?

Just as students brought in their own background knowledge into the pig dissection, they also brought in their knowledge of Spanish as native speakers. They would take advantage of opportunities to poke fun, with each other, of Linda's Spanish. Linda was seldom aware of these exchanges. The following example is from 
the second day of the pig dissection lesson. Linda has just given each student a pig and is getting ready to get them started on the dissection. Augusto points at his pig and comments that it is a female and, with Linda's prompting, identifies the sex of the other pigs near him:

Augusto: This is female

Linda: How can you tell if it's a female? ... OK, what about this? (points at another pig)

Augusto: (pointing at different pigs) this is a female that's a male that's a male that's a male

Carlos: este guey y este? [this dude and this?]

Linda: Do you understand which is which? Es hombre or mujer ... es hombre or mujer? [is it a man or a woman ... is it a man or a woman?]

Victor: es un puerco [it's a pig]

In Spanish, the words 'hombre' (man) and 'mujer' (woman) denote human gender differences. The sex of a pig would be indicated, instead, with a masculine or feminine ending on the word 'pig' ('puerco' or 'puerca') or by the use of the adjectives 'masculine'('masculino') or feminine ('feminina'). With this excerpt we see how students were aware of the limits of Linda's Spanish and took advantage of opportunities to comment on it, albeit it in a playful way. This kind of "teasing" took place throughout the lesson.

\section{Attitudes and habits of mind}

With respect to specific attitudes and habits of mind Linda wanted to promote in the pig dissection lesson, there is little explicit referencing of this. But we can make inferences informed by the context. From her referencing of their work in the meatpacking plant, it seems clear that she wanted students to see meaningful connections between what they were learning in their science class and their own lives. Since she has stated that the pig dissection is related to the work they have been doing on body systems, we see that she would like her students to make this curricular connection as well. We see her make these connections to students' previous learning when she asks students "what kind of animal is a pig?" because this references the previous learning they have been doing about the differences between mammals and reptiles.

But another aspect of the attitudes she is trying to promote has to do with students' willingness to even do the dissection in the first place. From the following examples, we see that the students are not all that interested in dissecting the pigs:

(From the first day)

Linda: Each person in here will be responsible for dissecting their own individual pig (while Linda is saying this, Rosa is shaking her head and saying "a mi me da cosa" - it makes me scared) to do Uds. a lunes necesito hacer una disección de tu mismo puerco

Rafael: (to Rosa) Tú lo vas a hacer? [Are you going to do it?] (Rosa shakes head) Juan: Yo no carnicero [I'm no butcher]

***

Linda: What I want you to do today is I want ... Edna ... to come up and I want you to look at this (the glass-encased preserved fetal pig)

를 Springer 
Edna: uuuhhhhhh huh (shaking head as if she really doesn't want to) $* * *$

Linda: Manuel ... did you look at ... where the book? Are you ready for ... Monday? Are you ready for Monday?(Manuel places his hand on his face; he does not reply) Silvio: tampoco yo estoy listo [I'm also not ready]

These excerpts show how the students, contrary to Linda's framing of the pig dissection as a promise she is fulfilling at their request, were not exactly eager and ready participants in the pig dissection lesson (Photo 6).

Science as a social practice

Interestingly, it was from the students, not Linda, that we see discussion of a science as a social practice being developed in the pig dissection lesson. Augusto develops this focus when he expresses an interest in understanding where Linda got these fetal pigs and raises the question of whether the activity is wasteful. On the first day of the activity, with Augusto's pressing, Linda uses his concerns to talk about why scientists need to use animals for such dissections:

(After Linda has presented the glass-encased fetal pig on the first day of the lesson) Augusto: Mrs. was that pig alive?

Linda: No

Augusto: it was dead?

Linda: It was dead ... it was not born alive ... ok? It was not alive when it was born $* * *$

(A bit later in the lesson, Augusto revisits his concern about where the fetal pigs come from)

Augusto: so Mrs

Linda: Yes sir

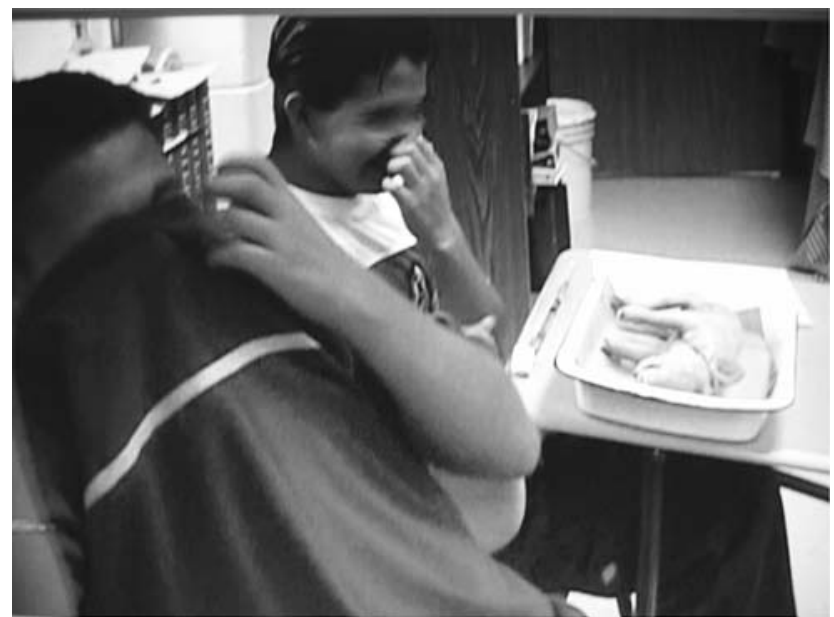

Photo 6 Students express disgust at the site and smell of the object of their dissection, a dead fetal pig 
Augusto: Does anyone like ... I see that this (referring to the glass-encased fetal pig) is something like something professional you know

Linda: Yes it is

Augusto: and I see that they said fetal fetal pig

Linda: (coming to stand closer to Augusto) fetal pig, uhu

Augusto: They do it you know ... they made the mother ... to have them ... premature or something? And they don't (inaudible)

Linda: Sometimes they do

Augusto: like they put some medicine so that she can throw them out?

Linda: Yeah, so that she goes into labor early ... that's true ... I don't know for sure ... how they go about it ... but I know that there are companies that we order the pigs from so there's companies that ... go through that ... and why do you think they do that?

Augusto: Huh? To investigate?

Linda: To investigate ... and remember through animals sometimes we can find cures for diseases ... that we can't always find ... if I look at Augusto I need a healthy person can I kill you to save this person's life? You would say no

Augusto: You can have my life ...

Linda: (patting him on the shoulder) no (laughing) Ok ... so ... that's a that's a ... question that we could investigate ourselves how do they come about ... to get so many fetal pigs?

$* * *$

(Before the end of the lesson on the first day, Linda returns to the topic raised by Augusto)

Linda: All of the systems of the body ... whether it be a pig or a person ... they're very complicated ... very complex ... los sistemas de los animals ... las personas ... tiene muchos cosas ... do we understand them completely?... we think we do ... but we're learning more and more ... since I ... hacer un pregunta por que nosotros usar los animals igual los puercos ... antes ellos tiene una chanza para vi vida ... we do it for science ... nosotros usar los animals para ciencia ... if we did not use animals we would not know a lot ... about us ... si nosotros no usamos animales y sus cuerpos ... nosotros no entender nosotros ... we wouldn't understand us ... porque los experimentos ... estar los animals ... disección con animales ... (to Mario) Mario, yo quiere mirar dentro de un cuerpo está bien si yo cortar tu estómago para mirar [Mario, I want to look inside your body is it $\mathrm{OK}$ if I cut your stomach to look] (Mario laughs and so does Linda). OK we wouldn't do that ... that is illegal to do ... but we can use animals specifically for science ... and there are people who protect animals as well.

Because of Augusto's questioning about where the fetal pigs come from, Linda is led to re-frame the dissection within a science-as-a-social-practice framework. In response to his prodding, she talks about the ethical issues of using animal and human bodies for scientific research purposes. Significantly, students' interests in this issue still don't go away:

(Later on that day as Linda is emphasizing that she wants all students to be involved) Linda: Every person on Monday will be required ... excuse me ... to dissect their own fetal pig

Augusto: Why don't you just go like 
Linda: Why don't I do that? Why do you think I want you each to do it? Augusto: I think may be (inaudible) waste ... you know like wasted ... you know like wasted pigs wasted pigs ... not everybody will want to do it $* * *$

(And on the very last day of the pig dissection lesson)

Sarah (one of the 2 Sudanese students): (inaudible)

Linda: This pig was never born

Sarah: (inaudible)

Linda: Yes ... remember? These pigs never had life

Sarah: Because they kill the mother and they just get them out?

Linda: Yeah

Sarah: (inaudible, with a facial expression of disbelief)

Marco: ¿Y todos estos puercos? ¿Cuántas mamás mataron, dos o una? [And all these pigs? How many mothers did they kill, two or one?]

Significantly, students' concern about where the fetal pigs come from seems to have been a central feature of their experience in the pig dissection lesson and it seems, for the most part, to be lost on Linda.

Standpoint summary of the science event

Considering the pig dissection as a science event from a standpoint perspective, from the perspective of the Mexican student participants, leads us to make three summary statements that reflect on these Science Event-related data. First, the purpose of the pig dissection lesson in the mind of these students was likely unclear. Linda framed the lesson as preparation for work in the hog plant, but she also framed the lesson with respect to future science course taking, to the work of doctors, and to the work of scientists doing research. These framings invoke very different purposes for the pig dissection lesson, from the development of highly specialized skills, to the completion of required coursework, to the performance of unskilled labor.

Second, in light of these different explicit framings of the lesson, features of the instructional environment provide implicit reinforcement of some of these framings over others. For example, the fact that this was an "EL Science" course, that Linda was not a science teacher, that she had limited Spanish proficiency and limited ELrelated strategies to engage these students in science conversations, all served to mark the class as a place where not much science was going to be learned. Additionally, there is the fact that the students were asked to do the pig dissection in an institutionally non-science setting (no lab tables, sinks, or protective clothing) using non-science tools (i.e., students were given what appeared to be Linda's kitchen knives to cut open the pigs). The lack of specialized knowledge, space, and equipment served to erode whatever claims Linda made about the pig dissection as preparation for highly skilled work and even called into question the connection of the lesson to the science curriculum.

Third, the way in which students' attempts to meaningfully connect the pig dissection to their lives were not substantively taken up even further reduced the possibility of their seeing the lesson as intellectually enriching. Neither their informal (out-of-school) prior knowledge related to pigs nor their formal (in-school) prior knowledge related to dissection were affirmed and, while there is evidence that Linda, 
when pressed by Augusto about the origin of the fetal pigs, found that concern compelling, discussion about the ethical dimension of animal use in science remains peripheral to the pig dissection lesson (even though these discussions are absolutely central to real-world science discourse). In sum, the practice of science constructed in the pig dissection science event in this course is one of stripped-away science expectations: there is no science classroom, there is no science teacher, there is no real acknowledgement of science-related connections and concerns, so in effect there are no science students. Given this, we can comprehend more fully the possibility (and power) of Linda's framing of the pig dissection as preparation for work in the plant.

Articulation 2: the pig dissection as a site of identity

In this section, we provide an account of how we saw the students and Linda constructing their identities through their relationships and personal experiences, and the role of voice, position, and power in those processes.

\section{Relationships}

In previous sections, Linda's relationship with her students might have shown through. She was a well-loved teacher. As previously mentioned, Augusto had a special fondness for her, and, from Richardson Bruna's longer-term work at the site, we know this kind of relationship with other students was not uncommon. She counseled girls through sexual relationships and was confided in by them, for example, during pregnancy scares (Richardson Bruna, Field Notes, October 11, 2005). One way she accomplished this sense of intimacy with her students was through physical contact like pats on the back or hugs. This was a substantially different kind of attention than the students got from other teachers.

Despite Linda's limited Spanish, clearly the fact that she spoke Spanish was something that facilitated her relationship with the students. While the students made fun of her Spanish, when asked they never complained about it. As Augusto explained, "pues que ... cuando oyen todo lo que dijo en inglés ... y después oyen lo que ... se los está repitiendo igual en español ... yo pienso que eso ayuda en una forma de que ... más o menos eso hace que ... de vez en cuando capte uno una palabra ... en inglés ... y ella al decirlo en español ya sabe uno que significa [well ... when they (the students) hear what she said in English ... and later they hear what she is repeating in Spanish ... I think that that helps because ... more or less it's like ... sometimes you catch a word ... in English ... and when she says it in Spanish you know that it means]."

Another important aspect of Linda's relationship with her students was her sense of humor. Frequently, Linda used humor to soften an admonishment. In the following example, Linda is admonishing Rafael for not working with his partner. When she finds out from Marco that it is Rafael's birthday, she turns this into a joke about giving him all the pigs as a birthday present:

(It is the last day of the pig dissection and Linda is concerned that Rafael is not helping his partner)

Linda: Rafael, are you helping your partner?

Rafael: Yep

Linda: How can you? Your partner is here and you've over there! Sooo, you're supposed to be helping 
Marco: (inaudible) cumpleaños

Linda: Yeah, it's your birthday so you get to help me with the pig

Pedro: Es lo que te vamos a hacer para el cumpleaños tuyo (that's what we're going to do for your birthday)

Linda: Para su cumpleaños nosotros ... de todos los los puercos (for your birthday we'll give you all the pigs)

Also common was the way that Linda, as a heavier woman, would make disparaging comments about her weight, comparing herself at times, in the pig dissection lesson, to a pig. Making fun of herself in this way, and the way she used physical humor, as in the following excerpt, was another important aspect of her relationship-building:

Linda You're gonna measure from the tip of the nose ... it's called the snout ... (She touches the tip of her nose with her right hand as she bends her head backward)... from the snout ... all the way ... to the rump ... this is your rump (and she gives herself a loud wallop on her behind and all the students laugh).

\section{Personal experiences}

As previously discussed, it is clear that students brought background knowledge into the pig dissection lesson, whether it was voiced or not, or whether it was acknowledged by Linda or not. Augusto, as Linda's main interlocuter, allows us to see what kinds of experiences these students might have found relevant to the lesson and, further, to understand what happens to classroom interaction when these experiences are shared. In the following excerpt from the first day of the pig dissection, we see how Augusto's sharing of his personal experience draws out Linda's own:

(Linda and Augusto have been talking about the gestation period for pigs. Augusto has shared what he knows about pig gestation from his farm in Mexico)

Augusto: And I also saw like when the pigs abort they were like pigs this big (accompanies with a hand gesture) a lot them there was like crystalline something crystalline something it was like jello do you know jello?

(several utterances later)

Augusto: And what happens where there is a pig that is like how do you call when there's a dead body is starting like

Linda: To decay?

Augusto: Yeah, but they're inside of the mother sometimes they came like pigs that are already decay like what happen with those

Linda: A lot of times if you don't get the pigs out soon enough um that can cause the mother to die

Augusto: No but at the time she's giving birth there comes like another ones like I don't know they got away from their or something like that because they are already decay

(This leads Linda into a conversation about miscarriage in which Augusto shares that his mother had two miscarriages and then Linda shares a story about her aunt's unusual pregnancy)

Linda: Sometimes in humans ... it is possible to be pregnant ... it is possible to be pregnant ... and the following month ... to have another egg get fertilized so you can have two different pregnancies a month apart 
Augusto: with a woman?

Linda: Uh huh. Mi tía my aunt un mes ella está embarazada con un bebé ... y lo próximo mes su cuerpo pasa un otro huevo y so ella (does downward hand motion) [My aunt was pregnant one month with a baby and the next month her body passed another egg and so she]

Rosa: Aborto (guessing that Linda is talking about a miscarriage)

Linda: Tiene un segundo ... so un bebé un mes . . la otro bebe . nueve [had a second . . so one baby .. one month, the other baby ... new (she has said 'nine' but she means 'new')

(Linda concludes her story by using it as an example of how complicated the body systems are and why we need to use animal dissections to study them.)

This exchange is important because it illustrates the kinds of personal experiences both students and teachers bring into the science classroom and how one person's story can activate another's. Notably, however, here we see take-up of Augusto's knowledge, interests, and experience, when it has previously been the case that Linda has generally ignored these. Apparently, the difference is that, in this case, Augusto has touched on a topic that Linda connects to and finds interestingmiscarriage and pregnancy. This reminds us that, despite her taking a more leveling voice by more genuinely conversing with Augusto here, she is still the one who holds the power in the classroom.

\section{Power: voice and position}

From the transcripts, it is abundantly clear that Linda held the floor most of the time in her classroom. She had few interlocuters and in those exchanges with other students, their turns lasted only a few words. A notable exception was Augusto, who, because of his more advanced language proficiency, had a different role in the course. His voice gave him more power and he used that power to act as a co-teacher of sorts with Linda, whether she liked it or not.

(From the first day of the pig dissection lesson. It is just minutes into Linda's introduction to the lesson and we see Augusto overlapping in speech with Linda as he answers a peer's question, in Spanish, about how the fetal pigs are preserved) Pepe: (referring to the glass-encased fetal pig) ¿y cómo se conserva allí? [how is it preserved there?]

Augusto: tiene la mitad [it has half] Linda: it is a chemical

Augusto (continuing to answer despite the fact that Linda has taken the floor): Tiene como el cincuenta por ciento de alcohol y lo demas de agua [It has like 50\% alcohol and the rest is water]

Linda: (waiting for Augusto to finish): It is in a chemical ***

Later, when Linda says that they will be using scalpels, Augusto jumps in with an admonishment to his peers to be careful:

Linda: You will have a scalpel ... and you will be doing the cutting

Augusto: Un bisturí ... esos son muy peligrosos no juegen con esos [A scalpel ... those are very dangerous don't play with those)

We also see him concerned about where they are going to do the pig dissection and the need to protect their clothes:

Springer 
Augusto: Are we going to do this in the classroom or are we gonna take it Linda: We will do it here

Rosa: Aquí?

Linda: We'll do it here

Augusto: Are we going to wear something like ... protection on our clothes

Linda: (to the whole group) If you want . . if you want protection over your clothes .. bring something like an old shirt

Importantly, Linda takes up his suggestion about the students needing to protect their clothes and, in doing so, confirms his contribution in his co-teaching role. Augusto's voice as a co-teacher in the classroom is made even more evident by how easily he slides into Linda's routine of traditional teacher questioning:

(From the first day)

1: Linda: You can see ... if you look at this book .. that a pig ... has the same systems that we have . . does the pig have a heart?

2: Augusto: Yes ... does the pig have blood . . yes, lungs

3: Linda: So ... if it has a heart and it has blood ... then it has a circulatory system ... right?

4: Augusto: Right

5: Linda: Does it have lungs?

6: Augusto: Yes

7: Linda: Does it breathe air?

8: Augusto: Yes

9: Linda: So it has a

10: Augusto: Respiratory system

11: Linda: Respiratory system ... does it have muscles?

12: Augusto: Yes

13: Linda: Does it have nerves?

14: Augusto: Yes

15: Linda: So it has

16: Augusto: A nervous system

17: Linda: A nervous system ... and a muscular system

18: Augusto: Does it have bones?

19: Linda: Does it have bones?

20: Augusto: Yes

21: Linda: Yes ... so what kind of system has bones?

Augusto adopts the teachers' voice in lines 2 and 18 by anticipating (and also answering in line 2) Linda's next question.

From the initial framing of the pig dissection activity as preparation for their future work in the meatpacking plant, despite students sharing their knowledge and personal experience, despite Augusto's voice as co-teacher, and despite the shared humor, the power encapsulated by that framing infuses throughout the lesson. Linda doesn't let the framing go:

(Towards the end of the first day of the lesson, as she's drumming up student interest in the dissection, we see this:

Linda: (to Enrique, grabbing his shoulder) are you going to be here Monday?

Enrique: (shakes his head no)

Linda: Why

Enrique: Because ... I don't like (mimes dissecting an animal) 


\section{Linda: But are you gonna work at the plant?}

Enrique: no

Linda: Good good, you're gonna go on to college (squeezes Enrique's shoulder then grabs Marco's shoulder, talks to him, and releases his shoulder)

On the second day, there is this:

Linda: Después de este ¿quien quiere trabajar en la planta? ... After doing this how many want to work in the packing plant?

And this:

Linda: (helping Rodrigo and Joel) This is just practice for working at the plant Joel: no es cierto porque allá allá ya van cortados, Mrs. [That's not true because there they already come cut, Mrs.]

Linda: You're gonna cut lomo, do you know what lomos are?

Rodridgo: Yeah ... los lomos son los de atrás [lomos are the backs]

The last excerpt is interesting because we have Joel directly challenging Linda's framing by asserting that the pig dissection isn't like meatpacking because at the plant they come already cut. Note how Linda proceeds with "you're gonna cut lomo," squarely repositioning Joel as a meatpacker, despite his challenge.

But some students, even Augusto, revoice the meatpacking frame. In this exchange, from the second dissecting day, Adolfo and Augusto talk about how they worked as butchers in Mexico:

Adolfo: Me recuerda cuando era matancera [this reminds me of when I was a butcher] Augusto: Y así pelaba los toros [this is how I cut bulls]

Adolfo: Yo pelaba toros cuando trabajaba [I cut bulls when I was working]

And in this exchange, Joel and Marco, playfully take up the idea that the pig dissection is, indeed, like food preparation:

Joel: ¡Hey sapo! Nos hechamos la cabeza p’hacer un pozole [Hey toad (a physical reference to Marco)! Let's cut off the head to make pozole (a traditional Mexican stew-like dish)]

Marco: Compre los tacos compre los tacos [Tacos for sale, tacos for sale]

These exchanges illustrate how Linda's framing of the pig dissection lesson as preparation for work at the plant found grounding in at least some students' previous work as butchers and their connections to pigs as a food source in Mexico. While it is tempting to ask whether Linda's framing actually precipitated these exchanges, we have no data to support that kind of causal relationship. We acknowledge it is perfectly possible that students might have engaged in these exchanges on their own. However, what remains clear is that Linda did little to support alternative interpretations of the connection between these students' lives and the pig dissection lesson, other than the meatpacking reference which she so very explicitly and, as it turns out, emphatically provided.

Standpoint summary of science identities

A standpoint perspective on science identities in the pig dissection lesson requires understanding the relationship, personal experience, and voice and position (power) 
aspects of the pig dissection lesson from the perspective of the Mexican students' experience. A review of these data produce the unmistakable impression that the pig dissection lesson, as a site of identity, was a conflicted and competing space. On the one hand, these students enjoy and have a fondness for Linda. She jokes with them and shares details about her life outside of school. As one of the only Spanishspeaking teachers at the school, she is their lifeline; her classroom is a refuge from the otherwise "uncaring"atmosphere of the school at large.

Linda's ability to care for these students, however, is brought into sharp relief by her insistent and repeated framing of the pig dissection lesson as preparation for their work in the plant, a framing, importantly, that she has initiated, at the beginning of the lesson, as a promise to them, which explicitly emphasizes the affective quality underlying Linda's relationships with her students. So even despite Augusto's stepping into the teacher role in terms of answering students' questions, warning against dangerous behavior, suggesting precautions to keep clothes clean, and closely mimicking traditional teacher-student school scripts-all manifestations of voice and position in the classroom, which, importantly, indicate intelligence and human agency-Linda continues to use her voice and position to re-center the subjugated social and economic identities of these students as unskilled laborers. In this way, the practice of science constructed through the pig dissection science identities in this EL Science course is one of stripped-away science agency. Linda's engagement in the affective realm of her students' lives informs us that she recognizes these students as fellow human beings, she is simply unable to extend to them any role in the social structure beyond the one with which she is familiar. She is normalizing and endorsing the racialized economic stratification of the community, while simultaneously playing the role of the sympathetic ally. In this way, the possibility of her framing the pig dissection lesson as preparation for work in the plant as a promise to them arises out of this tension between her conscious investment in nurturing affective relationships with her students and her unconscious privilege-based investment, as a white, middle-class individual in that community, in the current social and economic situation.

Articulation 3: the pig dissection lesson as a site of structure

Here we begin to move towards the discussion of the implications of all of the previously discussed interactions for understanding space and capital in the English Learner Science classroom at Captainville High. The other two features of Barton's practice of science perspective, science events and science identities, should be understood as shaping and being shaped by the structures of space and capital, to be described here, in the EL Science setting.

\section{Space}

The aforementioned interactions all took place within a particular temporal—spatial location (i.e., a demographically transitioning Midwestern meatpacking community in the era of globalization). This created particular kinds of spaces for the science teaching and learning of Mexican immigrant youth that are not incidental to, but constitutive of the schooling experiences of this population. A segregated community, segregated school, and segregated classroom created the possibility of Linda's framing of the pig dissection as an activity that was going to prepare them for their 
work at the plant. And we see that students, in the classroom space, both resisted and rearticulated this framing. It is important to state that it is quite possible that Linda, as she says, did not supply this framing without student influence. Thus, while Linda's words do perform a social action that can be understood as oppressive in that they reproduce the segregated nature of this community, there is reason to believe that Linda's saying of these words not just reproduced but also reflected the social practices already in play. Students and their families do come to this community to work at the plant. The possibility of her saying what she said does not begin entirely at the saying, but in the status quo of her community that reflects, in turn, the larger economic and social forces of global capitalism.

The Mexican economy is undergoing massive economic-policy restructuring as a result of its entrance into free trade agreements with the U.S. It has moved away from the kind of state-led development that characterized the post-revolutionary period and embraced increased privatization. In the rural sector, tariffs on agricultural products have been lowered, price guarantees eliminated, crop insurance cancelled, loans to peasant growers restricted, and 50\% of arable land targeted for privatized use. As a result, there has been a rise in migration from the rural sector, as members of the small landholder class-a reported $64 \%$ of them (Pastor \&Wise, 1997 , p. 354) - migrate to the US in order to earn enough money here to survive as farmers there (Pastor \& Wise, 1997). It is packing work at the plant that brings these families to Captainville, work they enthusiastically undertake because of the remesas, the remittances, it allows them to send home to those left behind to keep the farm, to feed bodies, and to improve their houses and communities. They are proud of their hard work and can see the results, not only in their own lives, but in the lives of Captainville's more long-term residents. They enumerate the ways they have boosted Captainville's economy, pointing to the community's need to expand retail outlets to accommodate their consumption, to a Main Street revitalized with Mexican entrepreneurs (Photo 7), to schools with enrollment highs.

They are engaged in an act of self-improvement for themselves and others and see the education their children receive in U.S. schools as a vast improvement over services available in the impoverished schools of their communities of origin (Richardson Bruna, Field Notes, May 22, 2006). At the same time that Captainville

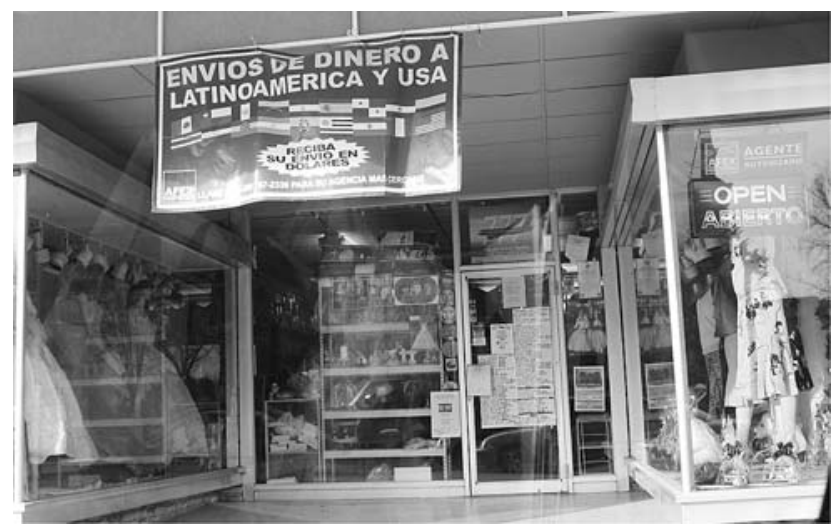

Photo 7 One of many Latino-owned businesses, now occupying traditional "American" retail spaces, that have enhanced the economic vitality of the community 
residents acknowledge these enhancements, they continue to begrudge Mexican immigrant families full community participation, with the apparent excuse that they are "just" workers at the plant. This is the ideology that played itself out in Linda's EL Science classroom space.

\section{Capital}

Capital refers to the resources activated in the English Learner Science classroom. These resources can be understood as physical resources, human resources, and social resources. In terms of physical resources, learning in this setting was constrained by the fact it was, as mentioned earlier, not a "real" science classroom. There were no sinks, lab tables, and lab coats. This did not escape the students' notice, as revealed by Augusto's surprise that they were going to do the pig dissection at their desks, in their regular clothes.

The nature of human resources-knowledge, skill, or capabilities present in this classroom-varied from student to student depending on level of language and literacy development in Spanish and English, as well as the extent of their science schooling in Mexico. Some, like Augusto, had very adequate science schooling and had previous experience, for example, with animal dissections in a science class. Likely many more also brought in the experiences that Augusto shared of his farm life in Mexico, that reflected lived experiences with and observations of animals. From our data, Linda did not systematically attempt to mobilize these experiences as a human resource for science learning. Indeed, her lack of interest in students' lives in Mexico and, further, even if she had the interest, her lack of the ability to coherently discuss those with her students, due to the language barrier, was a tremendous human resource issue. Augusto, in particular, for reasons we can only speculate, seemed intent on verbalizing the connections between Linda's coverage of the pig dissection and his own life and learning. Was it resistance (Giroux, 1983) to her framing of him as a future meatpacker? Was he simply trying to help his peers? Or was he trying to model the kind of behavior he said he felt they lacked, out of kindness for his favorite teacher?

This brings up social resources, or relationships among individuals and social institutions, in the English Learner Science class. Generally speaking, because many of these students were indeed newcomers, they didn't have easy access to support systems. The different patterns of being and behaving that Augusto references among Mexican youth might have put up walls between parties one might consider natural allies. From our familiarity with this school and community, we know there are very real tensions among newcomer youth, longer-term Mexican-origin youth, and U.S.-born Mexican youth, reflecting the pecking order of privilege. In this pecking order, newcomer youth, especially the undocumented, are at the bottom. The stigma of being a new arrival, with its tell-tale sign of no English proficiency, meant that there were, in fact, very few ways in which newcomers could access the social capital of other peers. This capital, in terms of access to someone who speaks English, can mean the difference between getting a failing or passing grade in a course because, with that person's help, a newcomer can complete assignments (which must be done in English) and turn them in to earn points toward a better grade. In Richardson Bruna's research at this site, newcomers don't fail for not coming to class or not participating in class. They fail because they don't turn in assignments (because they can't do them) or because they don't earn enough points on (English-language) 
assignments or tests. Access to social resources, in this case, can make all the difference. Yet getting access to these resources, for newcomers, was especially difficult.

Ironically, despite her framing of her students as future meatpackers, Linda was an important social resource for these students. Because she was well-liked and, undoubtedly because she could speak more Spanish than many other teachers and administrators in the school, students called on her for emotional and academic support. She was, for many, the only reason they continued to come to school. Other students have remarked to Richardson Bruna that, similar to her relationship with Augusto, Linda was familia [family] to them (Richardson Bruna, Field Notes, March, 13, 2006). This confronts us again with the tension made clear in the analysis of the critical incident between the Affective and Economic Discourses, her relational framing of the pig dissection as a promise and the academic and social outcome of that framing as a penalty. Further, we are reminded of Augusto's compelling explanation of the profound ambivalence Mexican immigrant students experience in feeling rejection from the white community while also feeling the need to keep up appearances (maintaining some protective distance, but not too much) in order to stave off further alienation. So, even if students took objection to (felt rejected by) Linda's framing of them as unskilled workers, they would have been careful not to jeopardize their relationship with her, as she was a most important source of "support" in the school. They were caught, as the Spanish saying goes, entre la espada y la pared, between the sword and the wall. They had little room to maneuver around power's sharp edge.

We are left with the unsettling conclusion that, no matter how tentative or guarded, students' confianza [trust] in Linda Crabtree was being betrayed by an aesthetics (as opposed to an ethics) of care (Noddings, 1984). Smiles, laughs, pats on the back, hugs, and even confidences about more intimate aspects of students' lives were taken as evidence, by both parties, of their caring relationship. But without attention to and action on systematically breaking down the systemic access-related barriers Mexican students encounter in schools, the good intentions of a teacher, like Linda, are nothing more than niceties. They create the appearance, among Mexican youth, that someone is attending to their needs, obscuring the many ways in which those needs continue to be ignored.

\section{Standpoint summary of science space and capital}

From a standpoint perspective, one that considers the Mexican immigrant students' "use" of space and capital, the EL Science course was one of stripped-away science access. The segregated space of the community, school, and EL classroom represented very real disparities in access to science-learning resources between middleclass white and Mexican immigrant students. The goal of overcoming these disparities would need to assume foremost importance in order to build a different practice of science amongst Linda and her students. Building a different practice of science itself requires, as Harvey's words remind us, a different "individual and collective imagination" (p. 159) about the world we build and the people we build it with.

\section{Towards an ethics of care}

Replacing calls for Science for All with deep attention to a practice of science, and the interrelationship between science events, identities, and structures, moves us 
closer to grasping what an ethics of care would mean with and for these students. The practice of science, what these students could do with and in science, as rendered by the pig dissection lesson in the English Learner Science course, was intimately influenced by the students' institutionalized statuses and Linda's related perception of their social and cultural capital. This affected the science-learning roles she attributed to them in the lesson, her inability to draw on their funds of knowledge (Moll, Amanti, Neff, \& Gonzalez, 1997) as resources for science learning, and the voice and positions she allowed them to take up. Thus the EL Science course stood to produce a particular kind of identity in relation to science, one that would do little to challenge current standards of who is a "scientist" (a "knower") and who is not.

A practice of science with these students rooted in an ethics of care, on the other hand, would, above all, consider the role of science learning in meeting these students' and families' wants and needs. It could be a place of language learning where they got access to what, for them, is a most precious resource-English. It could also be a place where the knowledge and skills they bring from their lives in Mexico was also considered a precious resource, something that affirms their human possibility and, as such, was a tool they could develop so that, regardless if they returned, as Augusto hoped to, or stay, as many do despite their hopes to return, they could better their own and others' lives. It could be a place where these "spaces of hope" become the space of science learning.

Given that farmers in the Midwest themselves have been disenfranchised by bigbusiness farming and many are trying to return to sustainable agricultural practices to reclaim their sovereignty, these students' and families' predicaments, pushed out as they are by a globalizing economy, should be a place of empathy. But this would require seeing past the barriers of culture, language, and class and envisioning a global citizenry whose lives, despite the barriers, are deeply intertwined. How ready are we to think that the education services we provide students here may not bear their fruit here, but there? This readiness demands a transnational understanding of human relationship, indeed, of schooling that rises above a nationalistic-creating good U.S. citizens-model, or models of science that are about increasing economic and technological growth and innovation, with U.S. gross domestic product and global security as the bottom lines. How ready are we to teach these students science, not limited by our conception that they'll never use it (because, after all, they'll be too busy, putting meat on our plates), but instead because we honor that they might have their own science purposes in mind, purposes that serve their and their communities' interests? To achieve that kind of practice of science with Mexican immigrant youth is putting their lives first. It is standpoint science and it requires a teacher, an architect, with a social imagination. After all, to imagine the sciencelearning lifeworlds (Habermas, 1984, p. 131, as cited in Lim \& Barton, 2006) of these students only through the lens of meatpacking is not just symbolic violence (Bourdieu, 1986), but a sanctioning against them of the real violence, the noted human rights abuses, that we know await workers in that industry. We, as teacher educators, must assist future teachers in imagining the science-learning lifeworlds of Mexican immigrant students differently.

In this paper, we have demonstrated that one way of transforming teachers' imaginations is by examining how what a teacher says in the classroom reflects and reproduces the larger context in which her or his teaching is actualized. Linda's framing of the pig dissection as preparation for the students' work at the meat- 
packing plant didn't materialize out of nowhere; it was, as Foucault says, "always already there" (1982, p. 210), a seething unspoken norm of the global, community, school, and classroom contexts that generated the conditions of its very possibility (Grossberg, 1997). But spoken, it assumed a different form and exerted a different force, and capturing that form and force on the practice of science generated between Linda and her students in the pig dissection lesson is what we have comprehensively attempted to do here.

\section{Reclaiming class in cultural studies}

Work carried out in the field of cultural studies typically is done so with three underlying premises. The first premise is that culture is a transaction of "lived practices," not something that is simply imposed and received from outside (Althusser, 1971, as cited in Agger, p. 10). The second is that conflict in meaning over how to assign value to human existence, expression, and experience (Agger, 1992, p. 10) is an inherent part of the cultural transaction and can result in transformative outcomes (Gramsci, 1971, as cited in Agger, p. 10). The third is that culture, understood as transaction and potentially transformative conflict, is inherently a political process that reproduces or redistributes power and resources (Agger, p. 11). Bringing these insights of cultural studies to bear upon science education helps us confront science as a transacted, conflicted, and political culture. They make science contested terrain and in so doing begin to accommodate alternative voices and versions (p. 12).

The advantage of critical discourse analysis, as a tool of cultural studies and critical educational ethnography, then, is its ability to show us how the transacted, conflicted, and political culture of science is realized, in this case, through classroom interaction between a teacher and her students. Its utility lies in its dual deconstructive and reconstructive capacity, in the way it asks us to confront how language in science classrooms is social action (Halliday, 1994) and, as such, when practiced mindfully, may take action to construct a different world. Linda's framing of the pig dissection lesson as preparation for her students' future work in the meatpacking plant contained linguistic choices that revealed patterns ("grammars") of interaction that were attested to in the larger ethnographic account of the practice of science in the English Learner Science classroom. Altering the linguistic choices simultaneously and necessarily alters the interactive patterns. Teachers then need to learn not only how to teach science in diverse settings (Barton \& Osborne, 2001) but also how to talk science in those settings (Lemke, 1990).

Importantly, examining the sum of Linda's interactions with her students points to the need to be cautious in our retreat from all manner of reductionism. While the idea of articulation as a theory and method in cultural studies-its emphasis on connotation, not denotation, and its rejection of totalizing truth claims-is appealing and helpful in staving off essentialized descriptions of believing, being, and behaving, we have concluded through this work that a return to the class-based analyses from which cultural studies has retreated is essential (Kelsh \& Hill, 2006). The explicit and emphatic production of these students' identities, within the science curriculum, as future workers in the plant notifies us of the need to confront the salience and determinacy of class in a capitalist economy.

For example, our efforts here revealed a significant tension between a teacher's "aesthetic" relationships with her new Mexican immigrant students and a substan-

Din Springer 
tive ethics of care. Informed by class analysis, this tension needs to be studied further so we can fully, and sensitively, understand the complexity of relationships developed among teachers and these students. We believe strongly that Linda wanted to be an agent of change in the lives of her students. How does class analysis help us understand her genuine ambivalent desire, to help her students, on the one hand, while keeping her (and her students) entrenched, on the other, in the dominant social and economic discourse of the community, school, and classroom?

As Lefebvre (1991), invoking Gramsci (1971) points out, a distinct and dominant aspect of capitalism is the hegemony of one class over another. As he writes:

Hegemony implies more than an influence, more even than the permanent use of repressive violence. It is exercised over society as a whole, culture and knowledge included, and generally via human mediation: policies, political leaders, parties, and also a good many intellectuals and experts. It is exercised, therefore, over both institutions and ideas. The ruling class seeks to maintain its hegemony by all available means, and knowledge is one such means (p. 10).

For Lefebvre, capitalist hegemony makes use of the production of any social space to establish its "system" (p. 11). Every social space contains, more narrowly, the reproduction of labor power (the working class) and, more broadly, the reproduction of the social relations of production that are constitutive of capitalism (p. 32). Thus to assert the relevance of class analysis to Linda's instruction in the English Learner Science classroom of Captainville High is not merely to propose that Linda's own class status and those of her students were at odds, it is to argue that in that "special" social space of her classroom we can observe "generalities" related to capitalist hegemony's exercise of power over institutions, ideas, and knowledge (Lefebvre, 1991, p.48). In this way, we can understand that, in some sense, "Every space is already in place before the appearance in it of actors"; it conditions their "presence, action, and discourse" (p. 57). In other words, it construes the "very conditions of the possibility of something" (Grossberg, 1997) that will emerge out of that space's social practices. In naming, through our "radical contextualization" of a practice of science, what we understand as a hegemonic force, we join our effort with those of others who provide witness, through ethnographic scholarship, of corporate domination in the classroom (Robertson, 2005) and call for heightened class-consciousness in research on the schooling of the Mexican new immigrant student population.

Early in this paper we shared our vision of education as a project of human possibility (Harvey, 2000). Mexican families who, in search of a better life, come to work at the plant in Captainville bring their own project of human possibility with them across the borderlands. We assert that a standpoint practice of science with Mexican students demands that these borderland identities are not regarded as "annoying exceptions" to classroom life (Rosaldo, 1989, in Jiménez, 2000). As Jiménez (2000) has remarked, borderland identities are the most culturally and linguistically productive spaces in contemporary society (p. 996). Why can't this also be true for contemporary science classrooms? Augusto had no difficulty seeing the connection between his experiences and concerns and the pig dissection lesson. We must help teachers, in Midwest meatpacking communities, and others, see, honor, and use those connections, with students, to create a new practice of science, one concerned not with line speed, but with social justice (Barton, 2003). 
Acknowledgments The data used in this paper were collected and managed under the auspices of an Iowa State University Special Research Initiation Grant. We gratefully acknowledge the support of those funds as well as the cooperation of the participating teacher and her students.

\section{References}

Agger, B. (1992). What is cultural studies? In Cultural studies as critical theory (pp. 1-25). London \& Washington, DC: The Falmer Press.

American Association for the Advancement of Science (AAAS) (1985). Science for all Americans. Online resource available at URL: http://www.project2061.org/publications/sfaa/online/sfaatoc.htm?ql (accessed May 31, 2006).

Barton, A. C. (2003). Teaching science for social justice. New York: Teachers College Press.

Barton, A. C., \& Osborne, M. D. (Eds). (2001). Teaching science in diverse settings: Marginalized discourses and classroom practice. New York: Peter Lang.

Building Engineering \& Science Talent/BEST (2004a). What it takes: Pre-K-12 design principles to broaden participation in science, technology, engineering, and mathematics. Online resource available at URL: http://www.bestworkforce.org/publications.htm (accessed May 31, 2006).

Building Engineering \& Science Talent/BEST (2004b). The talent imperative: Meeting America's challenge in science and engineering, ASAP. Online resource available at URL: http:// www.bestworkforce.org/publications.htm (accessed May 31, 2006).

Bowles, S., \& Gintis, H. (1976). Schooling in capitalist America. New York: Basic Books.

Bourdieu, P. (1986). The forms of capital, In J. G. Richardson (Ed.), Handbook of theory and research for the sociology of education. New York: Greenwood Press.

Catholic Legal Immigration Network (2000). Work without justice: Low-wage immigrant laborers (Report 3). Washington, DC: Catholic Legal Immigration Network.

Fairclough, N. (1995). Critical discourse analysis: The critical study of language. New York: Longman.

Foucault, M. (1982). The subject and the power. In H. L. Dreyfus, \& P. Rabinow (Eds.), Michel Foucault: Beyond structuralism and hermeneutics. Chicago: University of Chicago Press.

Gee, J. (1996). Social linguistics and literacies: Ideology in discourses. London: Falmer Press.

Gee, J. (1999). An introduction to discourse analysis: Theory and method. New York: Routledge.

Giroux, H. A. (1983). Theories of reproduction and resistance in the new sociology of education: A critical analysis. Harvard Educational Review, 53.

Goldin, L. R. (1999). Transnational identities: The search for analytic tools. In L. R. Goldin (Ed.), Identities on the move: Trasnational processes in North America and the Caribbean Basin. Studies on Culture and Society. (Vol. 7) (pp. 1012). Albany, NY: Institute for Mesoamerican Studies, University of Albany, State University of New York.

Gramsci, A. (1971). Selections from prison notebooks. London: Lawrence \& Wishart.

Grossberg, L. (1997). Bringing it all back home: Essays on cultural studies. Durham, NC: Duke University Press.

Habermas, J. (1984). The theory of communicative action: Vol 1. Reason and the rationalization of society. Boston: Beacon Press.

Halliday, M. A. K. (1989). Spoken and written language. Oxford: Oxford University Press.

Halliday, M. A. K. (1994). An introduction to functional grammar (2nd ed.). London: Edward Arnold.

Harding, S. (1998). Is science multicultural? Postcolonialisms, feminisms, and epistemologies. Bloomington and Indianapolis: Indiana University Press.

Harvey, D. (2000). Spaces of hope. Berkeley: University of California Press.

Human Rights Watch (2004). Blood, sweat, and fear. New York: Human Rights Watch.

Jimenez, R. T. (2000). Literacy and the identity development of Latina/o students. American Educational Research Journal, 37(4), 971-1000.

Kelsh, D., \& Hill, D. (2006). The culturalization of class and the occluding of class consciousness: The knowledge industry in/of Education. Journal of Critical Educational Policy Studies, 4(1). Online resource available at URL: http//www.jceps.com/index.php?pageID=article\& articleID=59 (accessed May 31, 2006).

Kyle, W. C., Jr (2001). Toward a political philosophy of science education. In C. Barton, \& M. Osborne (Eds.), Teaching science in diverse settings: Marginalized discourses \& classroom practices (pp. xi-xvii). New York: Peter Lang.

Laclau, E. (1977). Politics and ideology in Marxist theory. London: New Left Books. 
Lefebvre, H. (1991). The production of space. Oxford: Blackwell. (Translation by Donald NicholsonSmith).

Lemke, J. L. (1990). Talking science: Language, learning, and values. Westport, CT: Ablex Publishing.

Lim, L., \& Barton, A. C. (2006). Science learning and a sense of place in a urban middle school. Cultural Studies of Science Education, 1, 107-142.

Moll, L. C., Amanti, C., Neff, D., \& Gonzalez, N. (1997). Funds of knowledge for teaching: Using a qualitative approach to connect homes and classrooms. Theory Into Practice, 31(2), 132-141.

Noddings, N. (1984). Caring: A feminine approach to ethics and moral education. Berkeley: University of California Press.

Pastor, C., \& Wise, C. (1997). State policy, distribution, and neoliberal reform in Mexico. Journal of Latin American Studies, 29, 419-456.

Portes, A., \& Rumbaut, R. (2001). Legacies: The story of the immigrant second generation. Berkeley: University of California Press.

Richardson Bruna, K., Varun, R., \& Perales Escudero, M. (in press). What's language got to do with it?: A case study of academic language instruction in a high school "English Learner Science" classroom. Journal of English for Academic Purposes, 6(11).

Robertson, T. (2005). Class issues: A critical ethnography of corporate domination within the classroom. Journal of Critical Educational Policy Studies, 3(2). Online resource available at URL: http//www.jceps.com/index.php?pageID=article\&articleID=52 (accessed May 31, 2006).

Ruiz-de-Velasco, J., \& Fix, M. (2000). Overlooked and underserved: Immigrant students in U.S. secondary schools. Washington, DC: The Urban Institute. Online resource available at URL: www.urbaninstitute.org/pdfs/overlooked.pdf (accessed May 31, 2006).

Slack, J. D. (1996). The theory and method of articulation in cultural studies. In D. Morley, \& K.-H. Chen (Eds.), Critical dialogues in cultural studies (pp. 112-127). London: Routledge.

Spindler, G., \& Spindler, L. (1987). Issues and applications in ethnographic methods. In G. Spindler, \& L. Spindler (Eds.), Interpretive ethnography of education: at home and abroad (pp. 1-7). Hillsdale, New Jersey: Lawrence Erlbaum.

Spindler, G., \& Spindler, L. (1990). The American cultural dialogue and its cultural transmission. London, New York, and Philadelphia: The Falmer Press.

Trueba, E. T. (2004). The new Americans: Immigrants and transnationals at work. Lanham, MD: Rowman \& Littlefield.

U. S. Census Bureau (2004): Educational attainment in the United States. Detailed tables. Online resource available at http://www.census.gov/population/www/socdemo/education/cps2004.html (Accessed May 11, 2006).

Zuniga, K., Olson, J. K., \& Winter, M. (2005). Science education for rural latino/a students: Course placement and success in science. Journal of Research in Science Teaching, 42(4), 376-402.

Katherine Richardson Bruna is an Assistant Professor of Multicultural and International Curriculum Studies at Iowa State University. She is a former bilingual instructional aide and ESL teacher. Before taking her current academic position, she worked as a Research Scientist at the American Institutes for Research and was involved in evaluations of the implementation and effects of Proposition 227, California's "English-Only" initiative, and of California's Professional Development Institutes for teachers of English Learners. She has a long-standing interest in issues related to the education of Mexican immigrant children in U.S. schools. Her most recent research on the science-learning experiences of these youth has taken her into schools, communities, and households of rural central Mexico. She teaches undergraduate and graduate courses in multiculturalism and multicultural education, and on bilingualism, bilingual education, and U.S. Mexican youth.

Roberta Vann is a Professor in the Program of Teaching English as a Second Language and Applied Linguistics at Iowa State University where she teaches sociolinguistics, discourse analysis, and methods. Prior to her current position, she taught in Ethiopia and was a Fulbright lecturer in Poland. She later served as a consultant on second language learning in Syria, Slovakia, Peru, and Thailand. Her most recent research combines her interests in discourse analysis and pedagogy. 